\title{
The Global Conveyor Belt from a Southern Ocean Perspective
}

\author{
DANIELE IUdicONE \\ Laboratoire d'Océanographie et du Climat: Expérimentations et Approches Numériques, Unité Mixte de Recherche 7159, \\ CNRS/IRD/UPMC/MNHN, Institut Pierre Simon Laplace, Paris, France, and Stazione Zoologica Anton Dohrn, Naples, Italy \\ SABRINA SPEICH \\ Laboratoire de Physique des Océans, Unité Mixte de Recherche 6523, CNRS/IFREMER/IRD/UBO, Université de Bretagne \\ Occidentale, UFR Sciences, Brest, France \\ GURVAN MADEC \\ Laboratoire d'Océanographie et du Climat: Expérimentations et Approches Numériques, Unité Mixte de Recherche 7159, \\ CNRS/IRD/UPMC/MNHN, Institut Pierre Simon Laplace, Paris, France, and National Oceanography Centre, \\ Southampton, United Kingdom \\ BRUNO BLANKE \\ Laboratoire de Physique des Océans, Unité Mixte de Recherche 6523, CNRS/IFREMER/IRD/UBO, Université de Bretagne \\ Occidentale, UFR Sciences, Brest, France
}

(Manuscript received 16 December 2005, in final form 9 July 2007)

\begin{abstract}
Recent studies have proposed the Southern Ocean as the site of large water-mass transformations; other studies propose that this basin is among the main drivers for North Atlantic Deep Water (NADW) circulation. A modeling contribution toward understanding the role of this basin in the global thermohaline circulation can thus be of interest. In particular, key pathways and transformations associated with the thermohaline circulation in the Southern Ocean of an ice-ocean coupled model have been identified here through the extensive use of quantitative Lagrangian diagnostics. The model Southern Ocean is characterized by a shallow overturning circulation transforming $20 \mathrm{~Sv}\left(1 \mathrm{~Sv} \equiv 10^{6} \mathrm{~m}^{3} \mathrm{~s}^{-1}\right)$ of thermocline waters into mode waters and a deep overturning related to the formation of Antarctic Bottom Water. Mode and intermediate waters contribute to $80 \%$ of the upper branch of the overturning in the Atlantic Ocean north of $30^{\circ} \mathrm{S}$. A net upwelling of $11.5 \mathrm{~Sv}$ of Circumpolar Deep Waters is simulated in the Southern Ocean. Antarctic Bottom Water upwells into deep layers in the Pacific basin, forming Circumpolar Deep Water and subsurface thermocline water. The Southern Ocean is a powerful consumer of NADW: about $40 \%$ of NADW net export was found to upwell in the Southern Ocean, and $40 \%$ is transformed into Antarctic Bottom Water. The upwelling occurs south of the Polar Front and mainly in the Indian and Pacific Ocean sectors. The transformation of NADW to lighter water occurs in two steps: vertical mixing at the base of the mixed layer first decreases the salinity of the deep water upwelling south of the Antarctic Circumpolar Current, followed by heat input by air-sea and diffusive fluxes to complete the transformation to mode and intermediate waters.
\end{abstract}

\section{Introduction}

According to de Santillana and von Dechend (1992), some ancient cosmogonies consider the existence of a "mother fountain of all the waters of the world" (that is a confluence of all the existing waters, which rise and return there after completing their courses) and, inter-

Corresponding author address: Daniele Iudicone, Stazione Zoologica “A. Dohrn," Villa Comunale 1, 80121 Naples, Italy.

E-mail: iudicone@szn.it estingly, locate this fountain in the Southern Ocean. In the more recent classical "global conveyor belt" picture of the global ocean circulation, the nucleus is instead in the North Atlantic Ocean and adjacent basins that produce the dense North Atlantic Deep Water (NADW). In the Southern Ocean, this water blends with very dense waters produced along the shelves of Antarctica and eventually flows into the Indian and Pacific Oceans, where it upwells and starts its subsurface journey to the North Atlantic basin (e.g., Stommel and Arons 1960; Broecker 1987; Gordon 1986). While this 
Atlantic-centered scheme of the global thermohaline circulation (THC) has been flourishing in scientific publications, the role of the Southern Ocean has received little attention (see discussion in Sloyan and Rintoul 2001b, SR01 in the following). The recent analysis of the growing in situ dataset has shown that the region south of $30^{\circ} \mathrm{S}$ is the site of the largest oceanic watermass transformations (e.g., Mantyla and Reid 1983; Schmitz 1996a,b; Orsi et al. 1999; Speer et al. 2000; Sloyan and Rintoul 2000, 2001a; SR01; Blanke et al. 2002; Karstensen and Quadfasel 2002; Talley 2003; Talley et al. 2003, TRR in the following). Nevertheless, large uncertainties persist concerning pathways of the water masses, the role of the Southern Ocean in interbasin exchange, and the mechanisms governing the large buoyancy losses and gains (e.g., Speer et al. 2000; Sloyan and Rintoul 2000; SR01; Wunsch and Ferrari 2004).

Here we present an extensive application of a Lagrangian quantitative approach to the analysis of an ice-ocean model simulation with the aim of describing the global thermohaline circulation in a Southern Ocean perspective. We will focus on two specific, strictly interrelated issues. The first is to detail the pathways of interbasin exchange via the Southern Ocean and the associated water-mass transformations. To describe the many branches of the thermohaline circulation from in situ data is indeed a difficult task (e.g., Schmitz 1996a,b), and inverse models do not always converge on a unique picture of the circulation (Sloyan and Rintoul 2001b Ganachaud and Wunsch 2000; Macdonald 1998). The complexity of the pathways makes their definition difficult also when dealing with models, even in cases of a simple configuration (e.g., Goodman 1998, 2001). Wunsch (2000) recently presented an insightful reflection on the definition of oceanic thermohaline circulation. After reviewing several possible definitions, including the most notorious based on the concept of water mass, he concluded that the most suitable definition is that the THC is the ensemble of the streamlines of the large-scale flow. The obvious consequence in terms of analysis of oceanic datasets is that the Lagrangian approach is the most suitable for the purpose. Here we used a quantitative Lagrangian tool (Blanke and Raynaud 1997) that is explicitly designed for the analysis of the thermohaline circulation in general circulation models and that has already demonstrated its capability to extract unprecedented information from complex velocity fields (Blanke and Raynaud 1997; Blanke et al. 2002; Speich et al. 2001, 2002).

The second issue we address is the phenomenology of the overturning of Southern Ocean deep waters into subsurface waters, with focus on the NADW. After its formation, NADW flows southward at depth in the Atlantic basin and enters the Southern Ocean, where it becomes fresher and cooler (e.g., Wüst 1935). Modified NADW is thus a component of the Circumpolar Deep Water (CDW), a huge compound of water composed also of recirculations from the Indian and Pacific Ocean basins (Mantyla and Reid 1983) and whose fate is partly conversion into Antarctic Bottom Water (AABW) and partly upwelling (Sverdrup et al. 1942; Speer et al. 2000). It is, however, uncertain whether in the Southern Ocean this modified NADW is transformed into lighter water masses via the upwelling in the Antarctic divergence or, on the contrary, whether it contributes to the formation of AABW (e.g., Gordon et al. 1975; SR01; Webb and Suginohara 2001; TRR ; Wunsch and Ferrari 2004). Renewed interest in the issue is due also to its important implications for the amount of mixing energy required to maintain the thermohaline circulation (Toggweiler and Samuels 1998; Huang 1999; Webb and Suginohara 2001; Wunsch and Ferrari 2004). Some modeling studies propose that the NADW closes its loop in the wind-driven upwelling of the Southern Ocean; therefore a dependence of NADW circulation strength on the intensity of the Southern Ocean winds must be expected while the role of deep mixing and thus of external energetic sources is minor (e.g., Toggweiler and Samuels 1995; Gnanadesikan 1999; Hasumi and Suginohara 1999; Klinger et al. 2003). In fact, the actual mechanism that allows for NADW buoyancy gain in the Southern Ocean is still unclear (e.g., SR01; Klinger et al. 2004); other authors maintain that most of the buoyancy gains occur through diffusive processes in the tropics (e.g., Goodman 1998; Scott and Marotzke 2002). In a specific numerical sensitivity study, Rahmstorf and England (1997) found that it is AABW formation that actually depends on the wind intensity, which instead only modulates NADW formation. Here an analysis of the model NADW upwelling phenomenology is presented, with focus on the buoyancy gain mechanism. The upwelling of deep waters in the Southern Ocean in OGCMs has been described using numerical passive tracers, released at depth in the North Atlantic Deep Water (Hirst 1999; Goodman 1998). As acknowledged by Goodman (1998), the use of age tracers is the closest method to a Lagrangian approach, which is itself the most suitable. However, previous quantitative studies using a Lagrangian approach made use of model simulations that were not fully spun up (Döös and Coward 1997; Donners et al. 2005).

The present study complements the quantitative assessment of thermodynamic transformations occurring in the Southern Ocean within the same model (Iudicone et al. 2008b, IMBS08 in the following). In that pa- 
per, an extension of the diagnostic method of Marshall et al. (1999) was applied to the whole water column through neutral densities and including an internal buoyancy source: the solar penetrative heating [presented in Iudicone et al. (2008a)]. Those Eulerian results complement the Lagrangian analysis presented in this paper. The paper is organized as follows: the model is presented in section 2, the main characteristics of the Southern Ocean thermohaline circulation and its link with the global overturning are described in section 3, and the upwelling of NADW is presented in section 4 . The connection between the Lagrangian pathways and the thermodynamic transformations is discussed in section 5. A discussion of the implication of the results is presented in section 6 , and section 7 contains the summary.

\section{Model configuration and diagnostics}

The ice-ocean coupled model is the "ORCA2"-Louvain-la-Neuve Sea Ice Model (LIM) global configuration (Timmermann et al. 2005; see IMBS08 for more details). LIM is a fully dynamical-thermodynamical sea ice model (Fichefet and Morales Maqueda 1997). The ocean model ORCA2 is a free-surface global configuration of the Océan Parallélisé (OPA) model (Madec et al. 1998; Delecluse and Madec 1999). The horizontal mesh is based on a $2^{\circ}$ by $2^{\circ}$ Mercator grid. Lateral mixing is evaluated along isoneutral surfaces and is supplemented with the Gent and McWilliams (1990) eddy-induced velocity parameterization. The model background vertical diffusivity increases from the surface to the bottom. (Values range from $0.12 \times 10^{-4} \mathrm{~m}^{2}$ $\mathrm{s}^{-1}$ in the first $1000 \mathrm{~m}$ to $1.2 \times 10^{-4} \mathrm{~m}^{2} \mathrm{~s}^{-1}$ at depth.) At the surface, the ocean model is forced by computing fluxes of heat and freshwater (evaporation) with bulk formulas and by using monthly climatological descriptions of atmospheric forcings. A restoring to climatological surface salinities was also added. Climatological European Remote Sensing Satellite-1 and -2 scatterometer monthly mean wind stresses were used for the tropics, and the National Centers for Environmental Prediction-National Center for Atmospheric Research climatological dataset was used poleward of $50^{\circ} \mathrm{N}$ and $50^{\circ} \mathrm{S}$. To ease the comparison with inversions of in situ data, neutral densities were computed (McDougall 1987; Jackett and McDougall 1997). For the sake of simplicity, only six main water masses are here discussed, and they are defined in Table 1. For instance, we will refer to Indian Antarctic Intermediate Water (AAIW) as the water mass in intermediate water (IW) range (Table 1) that crosses $30^{\circ} \mathrm{S}$ in the Indian Ocean sector. The density partition in SR01 was used, with a
TABlE 1. Definition of water masses. Acronyms are Thermocline water (TW), Mode Water (MW), Intermediate Water (IW), Upper Circumpolar Water (UCDW), Lower Circumpolar Water (LCDW), and Antarctic Bottom Water (AABW). The IW range has been extended to 27.8 after inspection of the characteristics of the simulated water masses.

\begin{tabular}{cc}
\hline \hline Water masses & \multicolumn{1}{c}{$\gamma$} \\
\hline TW & $0-26.0$ \\
MW & $26.0-27.2$ \\
IW & $27.2-27.8$ \\
UCDW & $27.8-28.0$ \\
LCDW & $28.0-28.2$ \\
AABW & $28.2-$ bottom \\
\hline
\end{tabular}

separation of their intermediate class into mode and intermediate waters. The IW range was adapted to take into account the model cooler intermediate waters (see IMBS08).

The analysis was performed using an offline Lagrangian "Ariane" code (Blanke and Raynaud 1997). This diagnostic tool allows one to quantitatively track water volumes associated with a particular water mass (e.g., TRACMASS 2001; Blanke et al. 2002). For a given velocity field, the trajectories are analytically solved within each grid cell. This method allows the calculation of thousands to millions of trajectories for very long periods (Blanke et al. 2002). A fixed transport is associated with each trajectory. The particle seeding at the initial section is hence proportional to the crosssectional transport. As a result, our Lagrangian calculations are quantitative, whereas Lagrangian integrations in OGCM are often qualitative (e.g., Gu and Philander 1997). From the individual trajectories, a truly Lagrangian transport can be constructed between arbitrary sections for any water mass or flow (Blanke and Raynaud 1997).

In low- and intermediate-resolution OGCMs, time variability is in most cases limited to forcing variability, and thus we used a model time sampling of 14.6 days to resolve the main time scale of the forcing (see Valdivieso Da Consta and Blanke 2004). The maximum allowed transport for each particle is $10^{4} \mathrm{~m}^{3} \mathrm{~s}^{-1}\left(10^{-2}\right.$ $\mathrm{Sv}$ ) in most computations. Specific tests (forward-intime and backward-in-time integrations between sections) showed that the resulting accuracy in the transport computation is $\sim 0.1 \mathrm{~Sv}$.

\section{The main transformations in the global overturning in the model}

After a 1500-yr spinup, model drift is negligible and the last simulated year was used for the analysis. The simulated ocean circulation agrees with OGCM simu- 

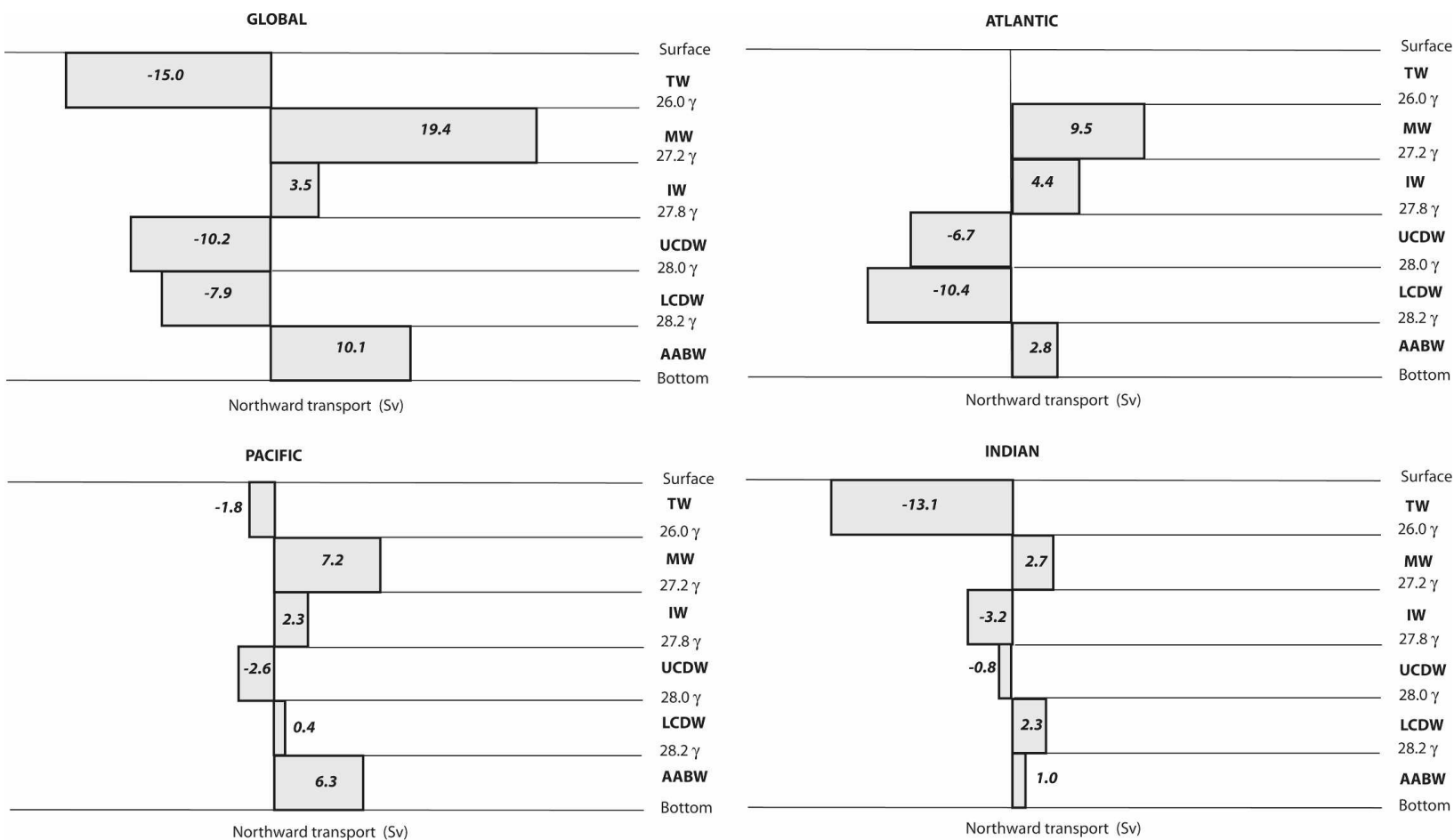

FIG. 1. The model meridional overturning at $30^{\circ} \mathrm{S}$.

lations with similar resolutions (e.g., England 1993; AABW overturning is $\sim 10 \mathrm{~Sv}$, with $\sim 3 \mathrm{~Sv}$ in the AtSørensen et al. 2001; Stammer et al. 2002); for example, lantic. A detailed validation was presented in Iudicone the intensity of the overturning in the Atlantic associ- (2007) and was summarized in IMBS08. The main ated with NADW formation is $\sim 18 \mathrm{~Sv}$ and the global model flaws are the weak deep circulation, the exces-

TABLE 2. Water-mass transformations in the Southern Ocean in the coupled ice-ocean model (Sv). The rows denote the fate at $30^{\circ} \mathrm{S}$ of the water masses entering the basin at $30^{\circ} \mathrm{S}$; the columns denote the origins at $30^{\circ} \mathrm{S}$ of the water masses leaving the basin on the same section. Percentages (in parentheses) refer to the fate of each water mass. For instance, it can be derived that $19 \%$ of the Atlantic UCDW flowing into the Southern Ocean (fourth row from top; total inflow is 9.7 Sv) leaves the Southern Ocean as Pacific AABW (12th column; total outflow is $6.3 \mathrm{~Sv}$ ). The diagonal elements are italicized.

\begin{tabular}{|c|c|c|c|c|c|c|c|}
\hline & & \multicolumn{6}{|c|}{ Atlantic Ocean origin } \\
\hline & & TW 2.6 & MW 18.5 & IW 11.2 & UCDW 3.0 & LCDW 3.7 & AABW 3.3 \\
\hline \multirow[t]{6}{*}{ Atlantic Ocean fate } & TW 2.6 & $0.7(26)$ & $1.8(68)$ & - & - & - & - \\
\hline & MW 9.1 & $0.3(3)$ & $6.4(71)$ & $1.0(10)$ & - & - & - \\
\hline & IW 6.8 & - & $0.4(6)$ & $3.3(48)$ & - & - & - \\
\hline & UCDW 9.7 & - & $0.5(5)$ & - & $1.1(12)$ & - & $0.4(4)$ \\
\hline & LCDW 14.1 & - & $0.3(2)$ & - & $0.3(2)$ & $3.4(24)$ & $1.6(11)$ \\
\hline & AABW 0.5 & - & - & - & - & - & $0.2(24)$ \\
\hline \multirow[t]{6}{*}{ Pacific Ocean fate } & TW 14.4 & - & - & - & - & - & - \\
\hline & MW 14.1 & - & - & - & - & - & - \\
\hline & IW 10.8 & - & - & - & - & - & $0.2(2)$ \\
\hline & UCDW 6.8 & - & $0.2(2)$ & - & - & - & $0.3(4)$ \\
\hline & LCDW 7.0 & - & $0.3(2)$ & - & - & - & $0.2(3)$ \\
\hline & AABW & - & - & - & - & - & - \\
\hline \multirow[t]{6}{*}{ Indian Ocean fate } & TW 18.2 & $0.6(3)$ & $2.3(12)$ & - & - & - & - \\
\hline & MW 31.8 & $0.4(1)$ & $5.4(17)$ & $0.2(1)$ & - & - & - \\
\hline & IW 16.8 & - & $1.0(6)$ & $5.4(32)$ & $0.2(1)$ & - & - \\
\hline & UCDW 5.3 & - & - & $1.1(21)$ & $1.0(20)$ & - & - \\
\hline & LCDW 5.3 & - & - & - & $0.2(3)$ & - & - \\
\hline & AABW 0.9 & - & - & - & - & - & - \\
\hline
\end{tabular}


sive ventilation of Indian Subantarctic Mode Water (SAMW), and the meridional misplacement of the Antarctic Circumpolar Current (ACC) fronts downstream of main topographic features. Also, the Atlantic meridional heat transport is about $0.7 \mathrm{PW}$ at $24^{\circ} \mathrm{N}$ and is thus less than most recent estimates (i.e., Ganachaud and Wunsch 2003).

Watermass transformations in the model Southern Ocean have been described and contrasted with available observational estimates in IMBS08 (here discussed in section 5). A diagram of net transports at $30^{\circ} \mathrm{S}$ is presented in Fig. 1. The model Southern Ocean shows a large deficit of thermocline water and CDW and a significant production of mode and bottom waters, consistent with the estimates of Talley et al. (2003) with the exception of the weak bottom circulation. The Southern Ocean receives thermocline water from the Indian Ocean while exporting mode water (MW) and IW to the Atlantic and Pacific Oceans. Most of the bottomwater excess flows into the deep Pacific layers.

Here we analyze the same steady-state circulation using a quantitative Lagrangian diagnostic to qualify and quantify the main branches of the overturning. The aim is to identify the pathways associated with the thermodynamic transformations described in IMBS08. The origin and fate of each water mass are computed by releasing numerical water parcels at $30^{\circ} \mathrm{S}$. We compute for each water parcel its trajectory, and we stop the integration when the parcel again reaches the $30^{\circ} \mathrm{S} \mathrm{sec-}$ tion. For computational stability, about one million particles have been used.

A global view of the resulting water-mass transfor- mations is presented in Tables 2 and 3 and is discussed in the following sections. Here we will use the notion of recirculating water mass in the broad sense of a water mass that leaves the Southern Ocean at $30^{\circ} \mathrm{S}$ in the same density class as it entered (i.e., the italicized values on the main diagonal in Tables 2 and 3).

\section{a. The role of the Southern Ocean in interbasin exchange}

The greatest contribution to interbasin exchange via the Southern Ocean comes from the Indian basin. This basin exports thermocline water (TW) and intermediate waters and imports mode and bottom waters. It presents the largest recirculation with little exchange with the Antarctic Circumpolar Current (Fig. 2a). The export occurs in the western boundary current and is mainly toward the Atlantic basin via a direct connection (Fig. 2b) to which it provides waters in all the density classes except for bottom water. An export pathway of mode and intermediate waters toward the Pacific is observed along the Subpolar Front.

The Atlantic imports mode, intermediate, and bottom waters and exports deep water [the NADW (Table $2)]$. The export occurs mostly in the western boundary current, but a significant amount flows into the Southern Ocean in the eastern South Atlantic. The recirculation in the subtropical gyre is significant, but part of the recirculation includes an exchange with the ACC (Fig. 3a). The Atlantic supplies large amounts of water to the other main basins (Fig. 3b): it supplies mode and deep waters to the Indian basin and thermocline and bottom waters to the Pacific basin.

TABLE 2. (Continued)

\begin{tabular}{|c|c|c|c|c|c|c|c|c|c|c|c|}
\hline \multicolumn{6}{|c|}{ Pacific Ocean origin } & \multicolumn{6}{|c|}{ Indian Ocean origin } \\
\hline TW 12.6 & MW 21.4 & IW 13.2 & UCDW 4.1 & LCDW 7.4 & AABW 6.3 & TW 5.0 & MW 34.3 & IW 13.8 & UCDW 4.5 & LCDW 7.4 & AABW 1.9 \\
\hline - & - & - & - & - & - & - & - & - & - & - & - \\
\hline $0.2(3)$ & $0.3(3)$ & $0.2(3)$ & - & - & - & - & $0.4(4)$ & - & - & - & - \\
\hline $0.5(7)$ & $0.4(6)$ & $0.3(5)$ & - & - & $0.3(5)$ & - & $0.7(10)$ & $0.2(3)$ & $0.2(3)$ & - & - \\
\hline $1.0(10)$ & $0.5(5)$ & $0.2(2)$ & - & $1.1(11)$ & $1.8(19)$ & - & $1.2(13)$ & $0.2(2)$ & $0.5(6)$ & $0.5(5)$ & - \\
\hline $0.8(5)$ & $0.3(2)$ & - & - & $1.2(8)$ & $2.2(16)$ & - & $0.8(6)$ & - & $0.2(2)$ & $2.1(15)$ & $0.5(4)$ \\
\hline - & - & - & - & - & - & - & - & - & - & - & - \\
\hline $8.1(56)$ & $6.2(43)$ & - & - & - & - & - & - & - & - & - & - \\
\hline $0.4(3)$ & $11.9(85)$ & $1.1(8)$ & - & - & - & - & $0.2(1)$ & $0.3(3)$ & - & - & - \\
\hline - & - & $7.9(73)$ & $0.2(2)$ & - & $0.2(2)$ & - & $0.2(2)$ & $1.6(15)$ & - & - & - \\
\hline $0.4(6)$ & $0.2(3)$ & 0.7 (11) & $3.0(45)$ & $0.4(6)$ & $0.6(8)$ & - & $0.4(6)$ & $0.3(4)$ & - & - & - \\
\hline $0.3(5)$ & $0.2(2)$ & $0.2(3)$ & 0.8 (11) & $4.2(60)$ & $0.4(6)$ & - & - & $0.3(5)$ & - & - & - \\
\hline - & - & - & - & - & - & - & - & - & - & - & - \\
\hline $0.2(1)$ & $0.4(2)$ & $0.2(1)$ & - & - & - & $4.7(26)$ & $9.7(53)$ & - & - & - & - \\
\hline $0.4(1)$ & $0.7(2)$ & $1.3(4)$ & - & - & - & - & $19.8(62)$ & $3.3(10)$ & - & - & - \\
\hline $0.2(1)$ & $0.2(1)$ & $0.8(5)$ & - & - & - & - & $0.2(1)$ & 7.4 (44) & $0.9(5)$ & - & - \\
\hline- & - & - & - & - & - & - & - & - & $2.4(44)$ & $0.4(8)$ & - \\
\hline- & - & - & - & - & - & - & - & - & $0.3(5)$ & $4.0(75)$ & $0.2(5)$ \\
\hline - & - & - & - & - & - & - & - & - & - & - & $0.7(81)$ \\
\hline
\end{tabular}


In the Pacific sector waters coming from the subtropics recirculate more than in other basins (Fig. 4a). The water masses that recirculate form two cores, flowing southward along the eastern Australian coast and north of New Zealand. The Pacific provides MW and IW to the Indian sector via a direct pathway south of Australia and bottom water to the Atlantic basin via the ACC (Fig. 4b).

\section{b. The pathways of Southern Ocean overturning}

The exchanges discussed above imply large watermass conversions that are described in the following (refer to Tables 2 and 3 ). Before proceeding with the analysis per water mass, we note here that in the model the ventilation of the water masses (a water parcel is considered ventilated if it has gone through the mixed layer in the journey from $30^{\circ} \mathrm{S}$ to $30^{\circ} \mathrm{S}$ in the Southern Ocean) accounts for about $80 \mathrm{~Sv}$, that is, more than $45 \%$ of the northward transport at $30^{\circ} \mathrm{S}$. In particular, most TW and MW are ventilated in the Southern Ocean (Fig. 5), whereas IW and CDW are only marginally involved in mixed layer processes. AABW formation implies significant surface mixing processes. The ventilation of the upper layers (TW, MW, and IW) adds up to $76 \mathrm{~Sv}$; that is, it is about $10 \mathrm{~Sv}$ larger than the estimate of Karstensen and Qaedfasel (2002).

To inspect qualitatively whether mixed layer processes were involved in the transformations, we restricted the computation of the percentages of venti- lated water parcels per water mass to the water parcels whose sources were not in the same density range (i.e., we did not consider recirculating water parcels). Almost the entire recently formed TW and SAMW northward flow at $30^{\circ} \mathrm{S}$ implies a subduction from the mixed layer, whereas only $30 \%$ of the AAIW is ventilated. About $35 \%$ of the AABW involves an entrainment in the mixed layer, and the percentage reduces to $15 \%$ for Lower Circumpolar Deep Water (LCDW) and becomes nil for Upper Circumpolar Deep Water (UCDW).

\section{1) Subsurface water}

About $35 \mathrm{~Sv}$ of thermocline waters flow southward across $30^{\circ} \mathrm{S}$ in the western boundary currents of the subtropical gyres, mostly in the Pacific and Indian Oceans. About $60 \%$ of these salty and warm waters are transformed into fresher and colder MW in the southern regions of the main subtropical gyres while the rest leaves the basin in the same density range. This overturning corresponds well to the shallow overturning in Talley (2003). The Indian Ocean basin presents the largest negative net exchange (the southward TW flow is in excess of $\sim 13 \mathrm{~Sv}$ with respect to the northward TW flow), and the largest conversion is into MW. About 3 Sv of Indian Ocean TW becomes Atlantic TW and MW. The TW leaving the Southern Ocean is instead composed mostly of recirculating TW $(70 \%)$, and the rest is of MW, IW, and CDW, in equal proportions in the mixture.

TABLE 3. Water-mass transformations in the Southern Ocean in the coupled ice-ocean model (Sv). The rows denote the origins at $30^{\circ} \mathrm{S}$ of the water masses leaving the basin at $30^{\circ} \mathrm{S}$; the columns denote the fates at $30^{\circ} \mathrm{S}$ of the water masses entering the basin on the same section. This table in fact is the transpose of Table 2, except that here percentages (in parentheses) refer to the origin of each water mass. For instance, here it can be derived that $35 \%$ of the Atlantic UCDW flowing northward at $30^{\circ} \mathrm{S}$ (fourth row from top) originally entered the Southern Ocean as Indian Ocean UCDW (16th column). The diagonal elements are italicized.

\begin{tabular}{|c|c|c|c|c|c|c|c|}
\hline & & \multicolumn{6}{|c|}{ Atlantic Ocean fate } \\
\hline & & $\mathrm{TW}$ & MW & IW & UCDW & LCDW & $\mathrm{AABW}$ \\
\hline \multirow[t]{6}{*}{ Atlantic Ocean origin } & TW & $0.7(26)$ & $0.3(11)$ & - & - & - & - \\
\hline & MW & $1.8(10)$ & $6.4(35)$ & $0.4(2)$ & $0.5(3)$ & $0.3(2)$ & - \\
\hline & IW & - & $1.0(8)$ & $3.3(29)$ & - & - & - \\
\hline & UCDW & - & - & - & $1.1(38)$ & $0.3(9)$ & - \\
\hline & LCDW & - & - & - & - & $3.4(93)$ & - \\
\hline & AABW & - & - & - & $0.4(13)$ & $1.6(49)$ & $0.2(7)$ \\
\hline \multirow[t]{6}{*}{ Pacific Ocean origin } & TW & - & $0.2(2)$ & $0.5(4)$ & $1.0(8)$ & $0.8(6)$ & - \\
\hline & MW & - & $0.3(1)$ & $0.4(2)$ & $0.5(2)$ & $0.3(1)$ & - \\
\hline & IW & - & $0.2(2)$ & $0.3(3)$ & $0.2(1)$ & - & - \\
\hline & UCDW & - & - & - & - & - & - \\
\hline & LCDW & - & - & - & $1.0(14)$ & $1.2(16)$ & - \\
\hline & AABW & - & - & $0.3(5)$ & $1.8(29)$ & $2.2(35)$ & - \\
\hline \multirow[t]{6}{*}{ Indian Ocean origin } & TW & - & - & - & - & - & - \\
\hline & MW & - & $0.4(1)$ & $0.7(2)$ & $1.2(4)$ & $0.8(2)$ & - \\
\hline & IW & - & - & $0.2(2)$ & $0.2(2)$ & - & - \\
\hline & UCDW & - & - & $0.2(4)$ & $0.5(12)$ & $0.2(5)$ & - \\
\hline & LCDW & - & - & - & $0.5(7)$ & $2.1(28)$ & - \\
\hline & AABW & - & - & - & $0.2(8)$ & $0.5(28)$ & - \\
\hline
\end{tabular}




\section{2) Mode waters}

Mode waters essentially recirculate $(86 \%)$, even if not necessarily in the same basin (Table 2), or are converted into denser waters (mostly IW). The origins of the MW not recirculating (38\% of the total northward transport) are essentially TW $(\sim 70 \%)$, while the rest $(8.4 \mathrm{~Sv})$ is the outcome of an upwelling of intermediate and deep waters. The largest net export is observed in the Pacific Ocean. The MW and AAIW in the South Atlantic are considered to be the return branch of the global thermohaline circulation (e.g., Gordon 1986; Sloyan and Rintoul 2001a). In our simulation, about one-half of the South Atlantic MW originates from the upper and intermediate layers of the Indian Ocean; the rest is in the recirculation.

\section{3) INTERMEDIATE WATERS}

In our simulation, even if AAIW is a water mass with clear southern origins, about $80 \%$ of IW recirculates; only one-tenth becomes TW, and the rest is transformed into UCDW and AABW (1 Sv). The Indian Ocean presents a net deficit of IW. The IW leaving the Southern Ocean is a mix of MW (18\%) and UCDW $(7 \%)$, while the rest is simply recirculation. The origins at $30^{\circ} \mathrm{S}$ of the Atlantic IW are in the western boundary current of the Indian Ocean $(59 \%$ with a $10 \%$ of UCDW) and in the recirculation in the basin subtropical gyre.

\section{4) UPPER CIRCUMPOLAR DEEP WATER}

We recall here that the model solution presents very weak deep flows relative to observations, especially for the Indian basin, and therefore the transformations discussed here and in the following section are probably biased. In our simulation, UCDW is largely consumed by the transformations occurring in the Southern Ocean by a net conversion into lighter layers $(33 \%)$ and into deep waters $(30 \%)$, equally distributed into LCDW and AABW. NADW entering into the Southern Ocean in the UCDW density class presents a complex fate. As illustrated in Table 2, the Southern Ocean acts as a powerful converter for this water mass. Most of its fate is in the Pacific; the rest is almost equally distributed between the Atlantic and the Indian Oceans. About $35 \%$ of the transport is converted into lighter waters, with a predominance of Pacific TW [as Subsurface Salinity Minimum Water (SSMW); Karstensen 2004] and Indian MW. A major part of these Atlantic water masses flows into the deep Pacific as UCDW (11\%) and AABW (20\%). (A more detailed analysis of the NADW fate will be presented in section 4.) The Pacific UCDW presents a somewhat weaker but equally complex conversion while the Indian Ocean UCDW basically presents an export to the Atlantic UCDW. The origins of the weak flow of UCDW leaving the Southern Oceans are in the recirculation (71\%), and the reminder originates from IW and LCDW.

\section{5) LOWER CIRCUMPOLAR DEEP WATER}

Part of LCDW recirculates (57\%); the rest is transformed into lighter water ( $6 \mathrm{~Sv}$, of which $\sim 4 \mathrm{~Sv}$ is into the upper layers, i.e., into TW, MW, and IW) and into AABW. The model Southern Ocean thus acts as a powerful converter of CDW, as proposed by Sloyan and

TABLE 3. (Continued)

\begin{tabular}{|c|c|c|c|c|c|c|c|c|c|c|c|}
\hline \multicolumn{6}{|c|}{ Pacific Ocean fate } & \multicolumn{6}{|c|}{ Indian Ocean fate } \\
\hline TW & MW & IW & UCDW & LCDW & AABW & $\mathrm{TW}$ & MW & IW & UCDW & LCDW & AABW \\
\hline- & - & - & - & - & - & $0.6(23)$ & $0.4(17)$ & - & - & - & - \\
\hline- & - & - & - & - & - & $2.3(12)$ & $5.4(29)$ & $1.0(5)$ & - & - & - \\
\hline- & - & - & - & - & - & - & $0.2(2)$ & $5.4(48)$ & $1.1(10)$ & - & - \\
\hline- & - & - & - & - & - & - & - & $0.3(8)$ & $1.0(35)$ & $0.2(6)$ & - \\
\hline- & - & - & - & - & - & - & - & - & - & - & - \\
\hline- & - & $0.2(5)$ & $0.3(9)$ & $0.2(7)$ & - & - & - & - & - & - & - \\
\hline $8.1(64)$ & $0.4(3)$ & - & $0.4(3)$ & $0.3(3)$ & - & $0.2(3)$ & $0.4(3)$ & $0.2(1)$ & - & - & - \\
\hline $6.2(29)$ & $11.9(56)$ & - & $0.2(1)$ & $0.2(1)$ & - & $0.4(2)$ & $0.7(3)$ & $0.2(1)$ & - & - & - \\
\hline- & $1.1(9)$ & $7.9(60)$ & $0.7(5)$ & $0.2(2)$ & - & $0.2(2)$ & $1.3(10)$ & $0.8(6)$ & - & - & - \\
\hline- & - & $0.2(4)$ & $3.0(74)$ & $0.8(19)$ & - & - & - & - & - & - & - \\
\hline- & - & - & $0.4(6)$ & $4.2(56)$ & - & - & - & - & - & - & - \\
\hline- & - & $0.2(3)$ & $0.6(9)$ & $0.4(7)$ & - & - & - & - & - & - & - \\
\hline- & - & - & - & - & - & $4.7(93)$ & - & - & - & - & - \\
\hline- & $0.2(1)$ & $0.2(1)$ & $0.4(1)$ & $0.3(1)$ & - & $9.7(28)$ & $19.8(58)$ & $0.2(1)$ & - & - & - \\
\hline- & $0.3(2)$ & $1.6(12)$ & $0.3(2)$ & - & - & - & $3.3(24)$ & $7.4(54)$ & - & - & - \\
\hline- & - & - & - & - & - & - & - & $0.9(20)$ & $2.4(52)$ & $0.3(6)$ & - \\
\hline- & - & - & - & - & - & - & - & - & $0.4(6)$ & $4.0(54)$ & - \\
\hline- & - & - & - & - & - & - & - & - & - & $0.3(13)$ & $0.7(39)$ \\
\hline
\end{tabular}


TW 4.7 Sv MW 29.9 SV

IW 11.2 SV

UCDW 3.5 SV

LCDW 4.6 Sv

AABW $1.1 \mathrm{SV}$

a)
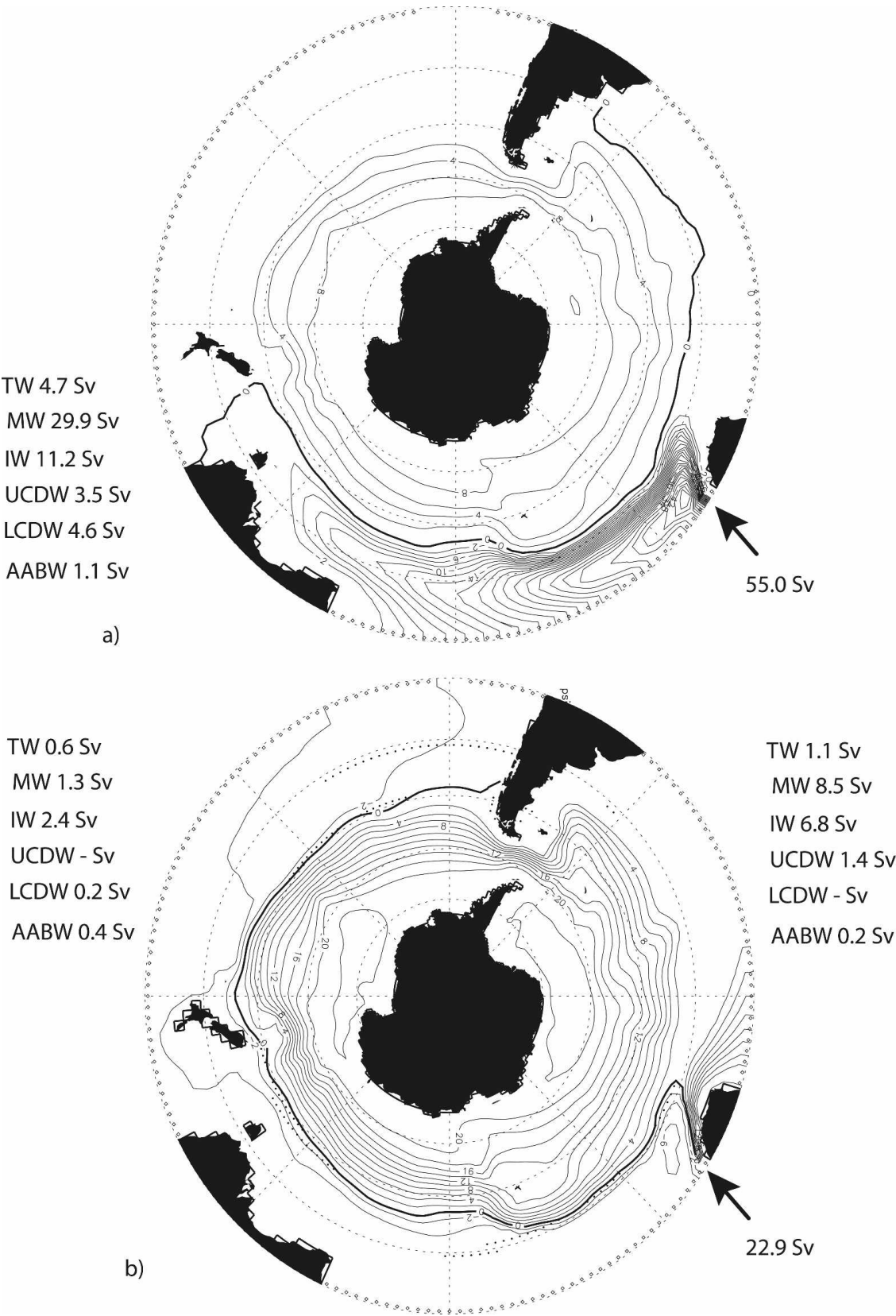

FIG. 2. (a) Lagrangian streamfunction of the vertically integrated transport of water masses entering the Southern Ocean at $30^{\circ} \mathrm{S}$ in the Indian Ocean sector of the basin and leaving the basin in the same sector. (b) Lagrangian streamfunction of the vertically integrated transport from the Indian Ocean to the Atlantic and Pacific Ocean basins. Isoline interval is $2 \mathrm{~Sv}$. The arrows indicate the injection windows into the Southern Ocean (only the total transport is reported here; see Tables 2 and 3 for details). The associated northward transports per water mass and per basin are also reported. The Lagrangian streamfunction is computed from the cumulative of the transports (from the Lagrangian trajectories) per grid box. Water parcels that move along quasi-closed paths around Antarctica promote an accumulation of transports per grid box that is representative of the time passed in the recirculation. 
a)

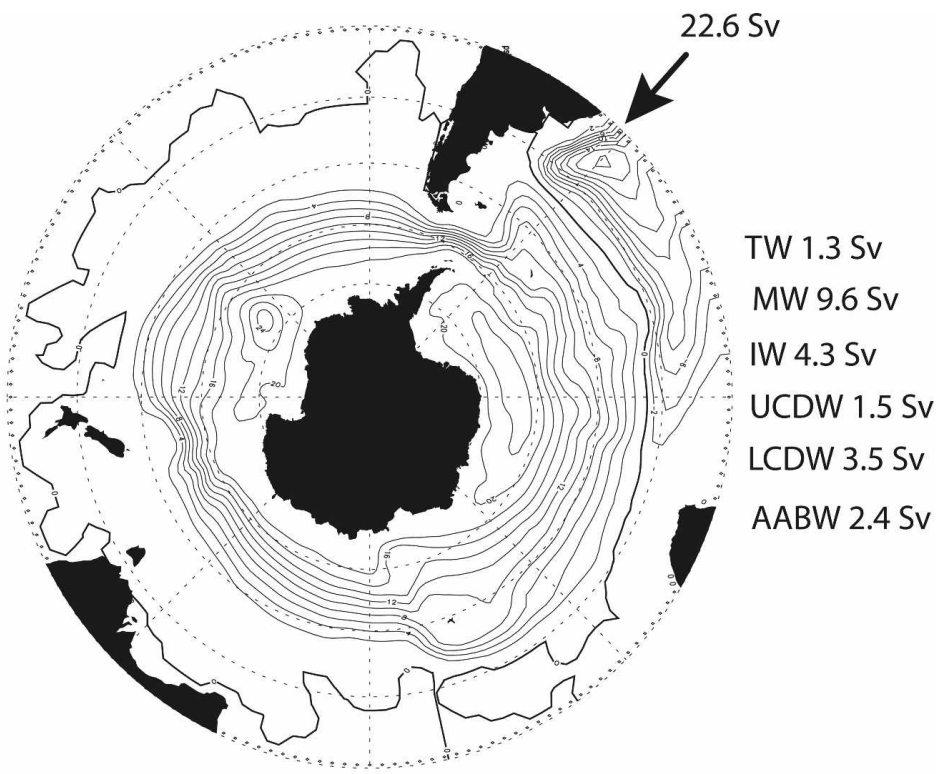

TW $2.5 \mathrm{SV}$

MW $1.3 \mathrm{SV}$

IW 0.9 Sv

UCDW - SV

LCDW 2.4 SV

AABW $4.5 \mathrm{~Sv}$

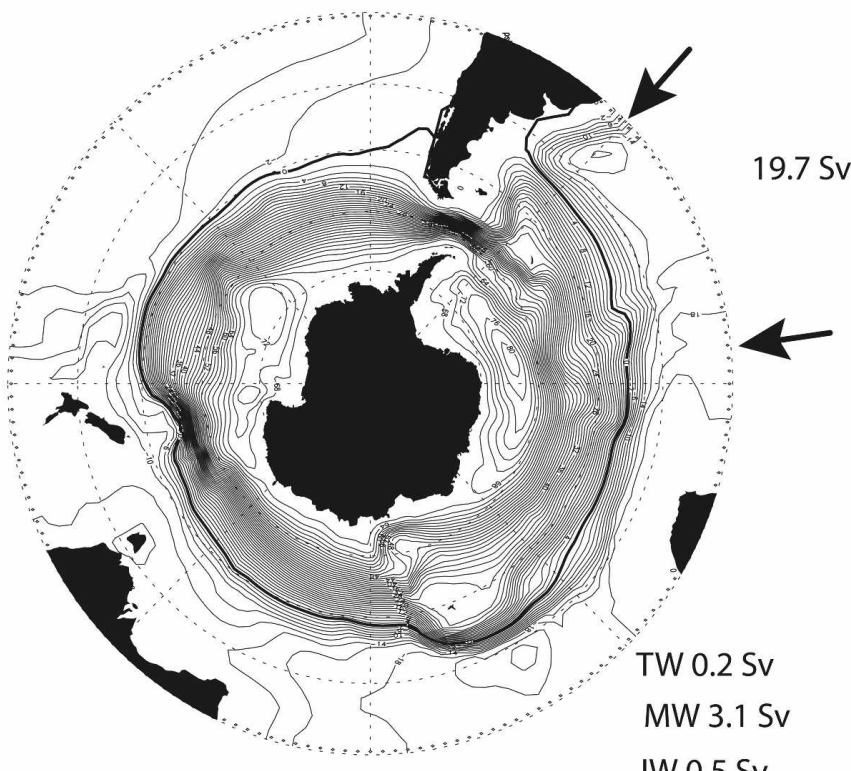

b)

IW $0.5 \mathrm{SV}$

UCDW $0.9 \mathrm{SV}$

LCDW $2.6 \mathrm{SV}$

\section{AABW $0.7 \mathrm{SV}$}

FIG. 3. (a) Lagrangian streamfunction of the vertically integrated transport of water masses recirculating in the Atlantic sector of the Southern Ocean. (b) Lagrangian streamfunction of the vertically integrated transport from the Atlantic Ocean to the Indian and Pacific Ocean basins. Isoline interval is $2 \mathrm{~Sv}$. The arrows indicate the injection windows into the Southern Ocean (only the total transport is reported here; see Tables 2 and 3 for details). The northward transports per water mass and per basin are also reported. See caption of Fig. 2 for further explanation.

Rintoul (2001b), the largest deficit actually corresponding to the consumption of NADW. In fact, also the NADW branch entering the Southern Ocean in the LCDW class spreads into several water masses, with a dominance of deep layers (22\% upwells; $43 \%$ recirculates, and more than one-half of this recirculation is into the Atlantic; $31 \%$ becomes AABW, with one-half of it flowing into the Pacific). The fate of the upwelling of 
TW 9.4 SV

MW $18.8 \mathrm{SV}$

IW 10.0 SV

UCDW 4.0 Sv

LCDW 4.7 Sv

AABW $1.3 \mathrm{SV}$

$48.2 \mathrm{~Sv}$

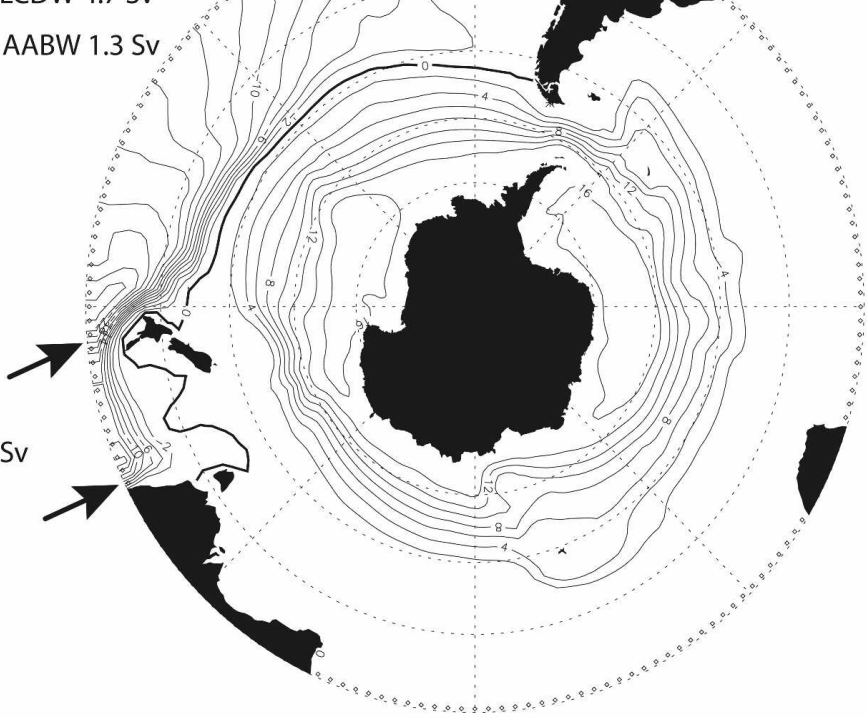

a)

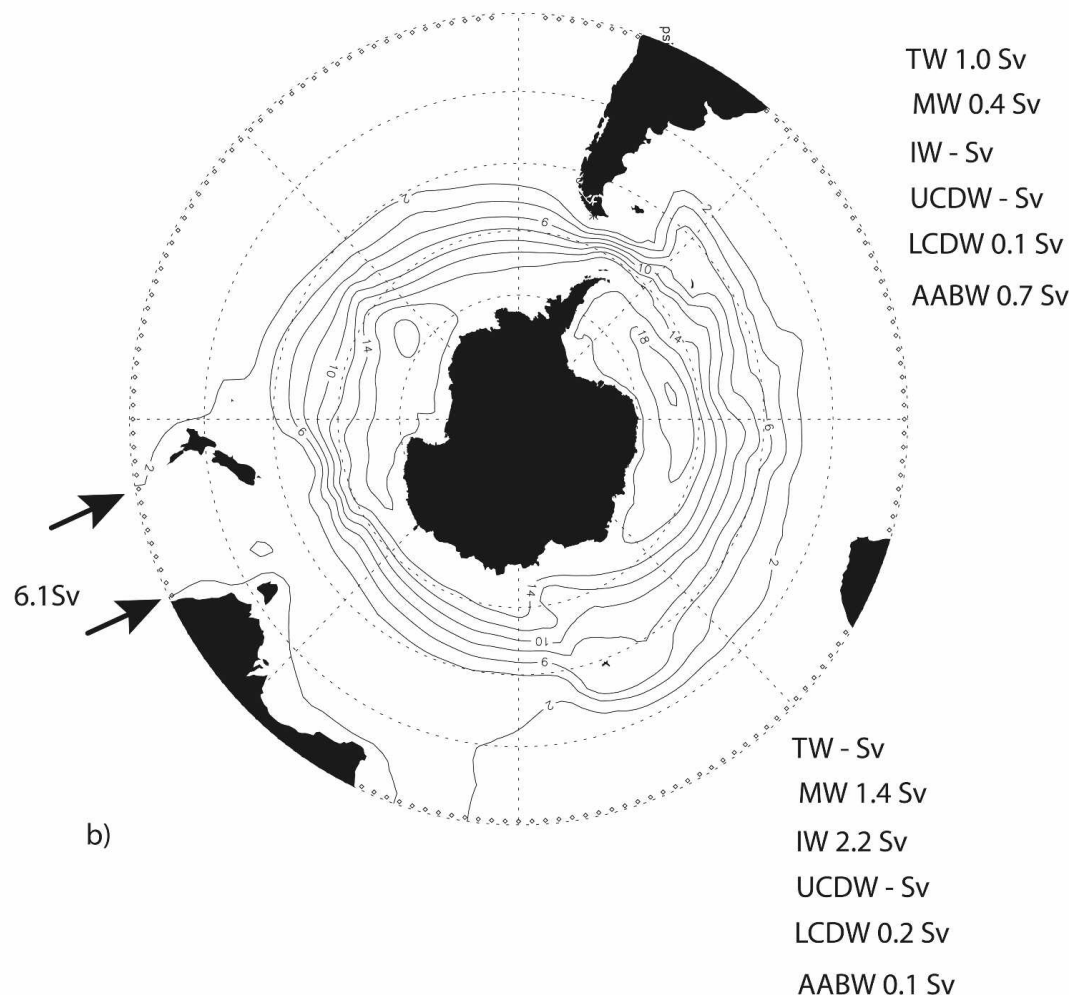

FIG. 4. (a) Lagrangian streamfunction of the vertically integrated transport of water masses recirculating in the Pacific sector of the Southern Ocean. (b) Lagrangian streamfunction of the vertically integrated transport from the Pacific Ocean to the Atlantic and Indian Ocean basins. Isoline interval is $2 \mathrm{~Sv}$. The arrows indicate the injection windows into the Southern Ocean (only the total transport is reported here; see Tables 2 and 3 for details). The northward transports per water mass and per basin are also reported. See caption of Fig. 2 for further explanation. 


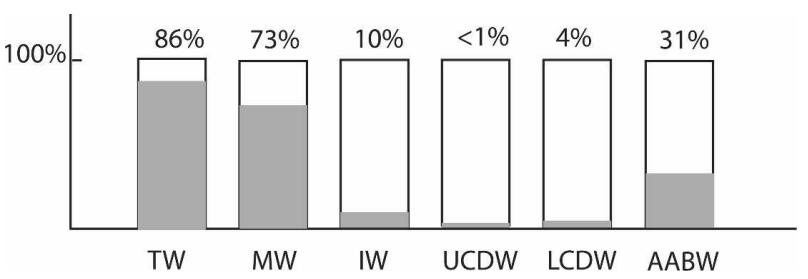

FIG. 5. Ratio of the transports at $30^{\circ} \mathrm{S}$ associated with water parcels flowing from the Southern Ocean mixed layer over the total transport at $30^{\circ} \mathrm{S}$ per water mass.

the dense NADW is similar to the fate of the upwelling of NADW in the UCDW density range discussed above.

The only contribution to the LCDW leaving the Southern Ocean at $30^{\circ} \mathrm{S}$ is from UCDW; in fact $80 \%$ of LCDW recirculates. A net export of LCDW (NADW) from the Atlantic to the other basins is simulated.

\section{6) Antarctic bottom water}

The weak flow of water in the AABW density range that flows southward into the Southern Ocean essentially recirculates. The mixture of water forming the AABW consists of, in order of significance, IW, UCDW and LCDW. The amount of CDW transformed into AABW is large ( $9 \mathrm{~Sv}$ ) and represents $75 \%$ of the total export. This corresponds to the deep overturning cell in Speer et al. (2000). The Pacific basin represents the main sink of AABW. It is interesting that a direct and important interbasin connection emerges from the analysis of the origins of the bottom water flowing northward into the Pacific in the AABW range because most of its sources are in the Atlantic (64\% is NADW). The CDW exiting from the Pacific contributes a mere $15 \%$.

\section{7) Summary}

A sketch of the main thermohaline conversions in the Southern Ocean is presented in Fig. 6. Three main thermohaline cells characterize the model Southern Ocean: the shallow overturning of TW into MW, a deep overturning (CDW into AABW), and the net upwelling of deep waters (mostly CDW) into TW and MW, flowing into the Pacific and Indian Oceans, respectively. The upwelling rate of CDW is about the same as the transformation into bottom waters, partially at odds with Speer et al. (2000), SR01, and TRR, who proposed a fate of CDW mostly into mode water for UCDW and bottom water for the LCDW, respectively. The IW appears to be relatively independent from the main Southern Ocean thermohaline cells; of interest is that the main contribution to its formation is a cooling and freshening of MW. The implications of these results are discussed in section 5 .

\section{c. The connection with the global thermohaline circulation and the role of the Indonesian Throughflow}

The link of the thermohaline circulation in the Southern Ocean with the overturning at global scale has been investigated by extending the parcel trajectories north of $30^{\circ} \mathrm{S}$ and stopping them when again crossing this latitude; water parcels that evaporated were excluded.

\section{1) Atlantic Ocean}

In the Atlantic, thermohaline circulation MW dominates AAIW in the NADW formation (Fig. 7a). In general, about one-half of TW, MW, and IW recirculates and the rest becomes NADW (Fig. 7a); CDW in fact recirculates while AABW essentially upwells and becomes NADW.

\section{2) PACIFIC OCEAN}

In the Pacific Ocean (Fig. 7c) thermocline waters recirculate locally $(70 \%)$; the rest is transformed into Indian Ocean TW. The MW and IW recirculate or become Indian Ocean TW. Most of the UCDW recirculates. A small amount of LCDW upwells into UCDW (15\%) and Indian Ocean TW (6\%). The deep upwelling is instead more efficient for AABW, possibly because the area in which the large near-bottom vertical diffusivity and the bottom geothermal flux can promote the overturning is larger. (Sensitivity experiments reported elsewhere showed that the enhancement of the deep diffusivity with respect to a constant value of $10^{-4} \mathrm{~m}^{2} \mathrm{~s}^{-1}$ promotes an extra $\sim 3-4$ Sv Pacific deep overturning while the geothermal bottom flux promotes an extra $\sim 1.5 \mathrm{~Sv}$.) AABW turns basically into CDW but also into Indian Ocean TW $(22 \%)$ and $\mathrm{Pa}-$ cific TW (13\%). The upwelling of deep water represents therefore a small percentage of its inflow (as proposed by SR01; here the upwelling across 27.8 is $2-3$ $\mathrm{Sv})$, and the fate of this upwelling is in Indian Ocean TW, which also collects part of the Pacific TW. Indian Ocean TW reenters the Southern Ocean and basically forms Indian Ocean MW (Table 2), whereas only $3 \mathrm{~Sv}$ enter directly into the Atlantic. The upwelling across 27.8 is about $2-3 \mathrm{~Sv}$.

The observed export to the Indian Ocean (Fig. 7c) implies a pathway through the Indonesian Passages whose southern origins are not well known (see discussion in SR01). In our model the Indonesian Throughflow net transport (13 Sv; a recirculation in the passage gives that only $10.8 \mathrm{~Sv}$ is actually flowing into the Indian Ocean basin) is close to observations (Godfrey 1996). More than one-half of the net injection of AAIW into 


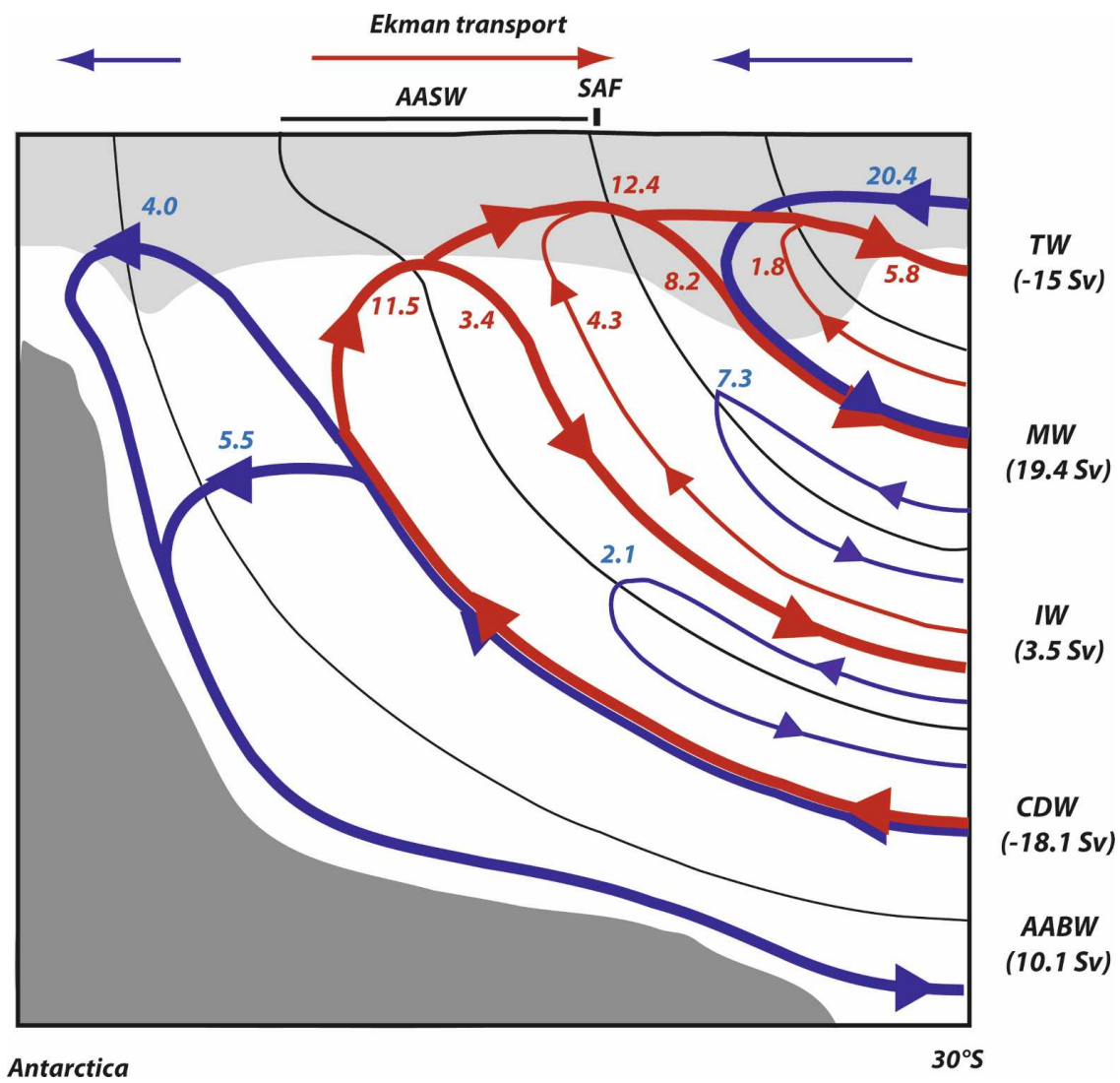

FIG. 6. "The mother fountain of all the waters of the world": a sketch of the thermohaline circulation in the Southern Ocean in the ice-ocean model. (Sv; the net transports in Fig. 1 are reported in parentheses.) For the sake of simplicity, UCDW and LCDW have been merged into a unique CDW layer and the upper layers have been stretched in the vertical direction. The dark-blue pathways correspond to buoyancy losses; red pathways correspond to buoyancy gains. The shallow overturning, the deep overturning, and the upwelling of CDW (i.e., the main overturnings discussed in the text) are represented by thick lines. Note that the main source for AAIW is MW. The light-gray shading sketches the mixed layer depth. The direction of the Ekman meridional transport is reported as well as the position of the Subantarctic Front and the region occupied by AASW.

the South Pacific in the model has its fate in the Indonesian Throughflow-indeed a small transport in absolute values. Upper layers (TW and MW) explain most of the transport, as proposed by SR01. Last, $20 \%$ of the Indonesian Throughflow was originally AABW-that is, one-third of its net inflow in the Pacific.

\section{3) INDIAN OCEAN}

The upper layers (Fig. 7b) essentially recirculate in this basin, with some significant internal exchanges, while a convergence of upper and deep waters goes into IW (in agreement with SR01). Less than $1 \mathrm{~Sv}$ of TW transforms into MW. The MW largely recirculates (84\%) while the remainder converts into TW and IW (2.3 Sv). (This conversion of MW into the denser IW in a tropical basin is noteworthy; it is probably due to nonlinear thermodynamic processes: namely, cabbeling; see also You 1998). The recirculation of IW (90\%) is even larger than for MW; the rest upwells. Deep layers, whose circulations are very weak in comparison with observations (e.g., SR01 and references therein), present an intense upwelling that is confined to the adjacent layers and thus is not involving TW or MW. The UCDW recirculates $(84 \%)$ or transforms into the AAIW layer. LCDW is more scattered because $66 \%$ recirculates; $12 \%$ becomes TW, IW, and UCDW. The weak AABW flow recirculates or converts into LCDW and AAIW. The Indian Ocean in our simulation thus basically acts as a transitional basin between the Southern Ocean and the Atlantic upper circulation and between the Pacific Ocean and the Southern Ocean. 


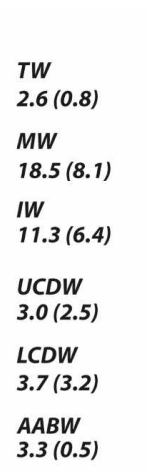

$s$

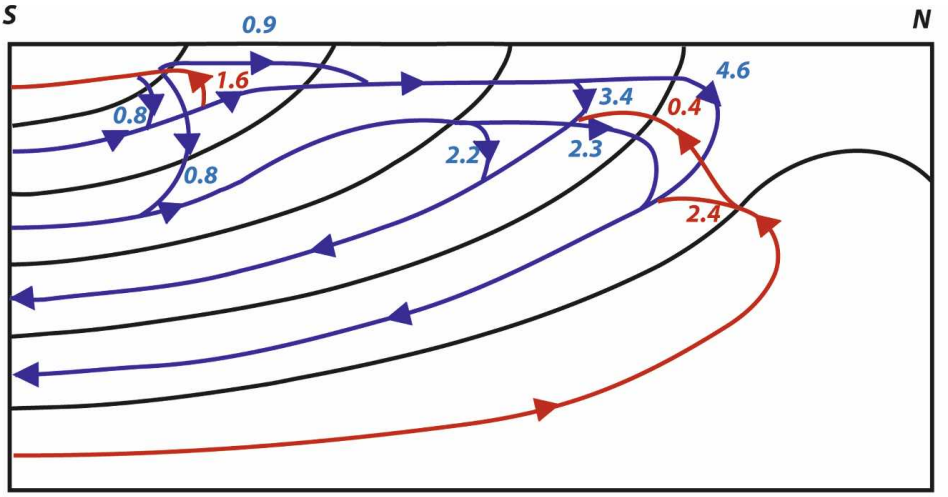

ATLANTIC BASIN

a)

TW

$5.0(4.2)$

MW

34.2 (28.7)

IW

13.8 (12.3)

UCDW

4.5 (3.8)

LCDW

7.4 (4.9)

AABW

$1.9(0.9)$

b)

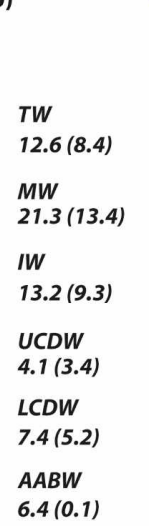

c)
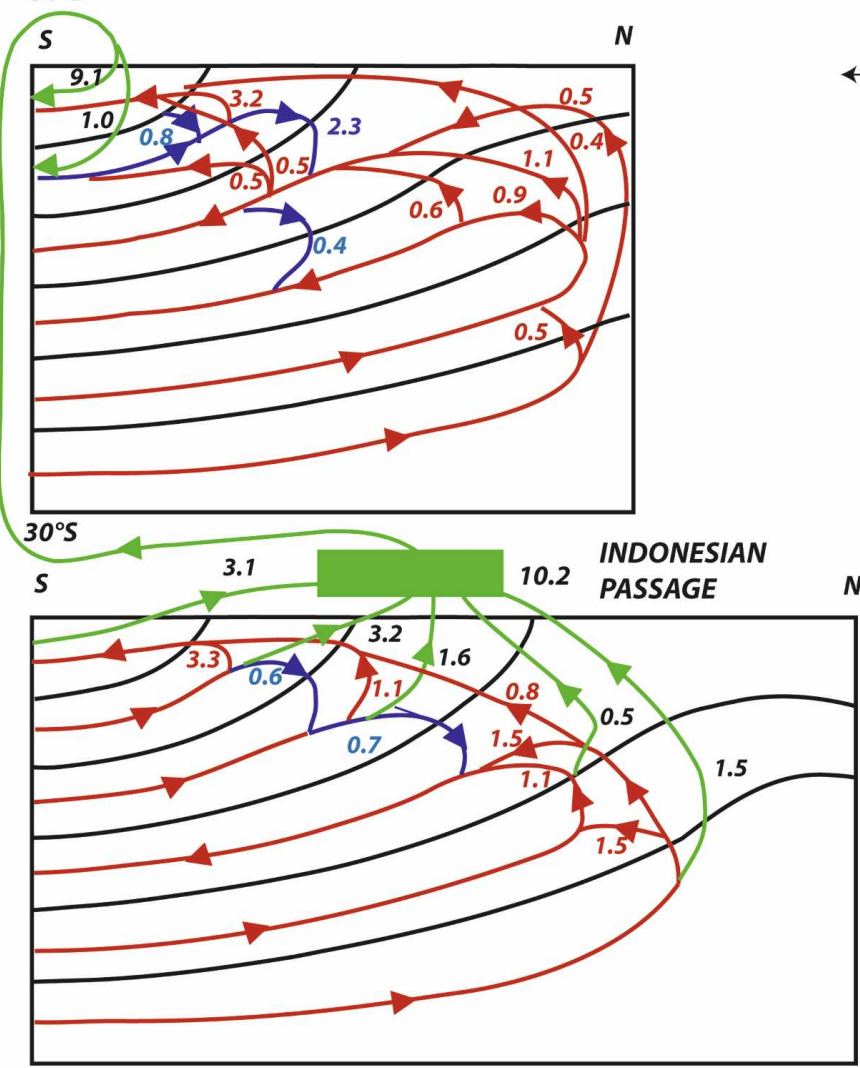

$30^{\circ} \mathrm{S}$

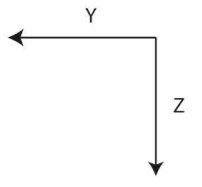

INDIAN BASIN

PACIFIC BASIN

FIG. 7. (a) Sketch of the transformations occurring in the Atlantic Ocean basin north of $30^{\circ} \mathrm{S}(\mathrm{Sv})$. Figures correspond to transports from layer to layer (Sv) and, as in Fig. 6, the dark-blue pathways correspond to buoyancy losses and red pathways correspond to buoyancy gains. On the left, the northward transport is also reported with, in parentheses, the recirculation on the same isoneutral horizon. (b) As in (a), but for the Indian Ocean basin. (c) As in (a), but for the Pacific basin. The small box sketches the Indonesian Passage, and green lines represent the contribution of the Pacific water masses to the southward transport in the Indian Ocean sector at $30^{\circ} \mathrm{S}$. The value reported here for the transport in the Indonesian Passage is 10.2 instead of 10.8 (see text) because this value is the transport that results from the backward integration from $30^{\circ} \mathrm{S}$ in the Indian Ocean basin. The mismatch is due to water parcels evaporating in the subtropical Indian Ocean basin.

\section{The upwelling of NADW in the Southern Ocean}

In our simulation a large amount of the net export of NADW from the Atlantic to the Southern Ocean is transformed in the latter basin $(\sim 70 \%-80 \%)$. To illustrate further the link between the overturning in the Atlantic and the Southern Ocean thermohaline circulation, the description of the fate of the upwelling 
branch of the NADW is given in more detail together with the analysis of the physical processes responsible for it.

\section{a. The characteristics of the upwelling of NADW}

We define here "NADW upwelling" as the ensemble of NADW water parcels, that is, the water parcels that compose the southward flow in the density range of CDWs at $30^{\circ} \mathrm{S}$ in the Atlantic, that are lighter than CDW (i.e., having a value of $\gamma>27.8$ ) once leaving the Southern Ocean. We will focus first on the parcels' first crossing of the upper CDW isosurface $(\gamma=27.8)$, a criterion related to the notion of overturning and not merely to the uplift of the water mass (Döös and Coward 1997; Hirst 1999; Gnanadesikan et al. 2003). The geographical distribution of the dianeutral velocity associated with the NADW first upwelling (Fig. 8a) shows that most of the upwelling occurs south of the ACC fronts. The major upwelling sites are located south of the African continent, between $70^{\circ}$ and $60^{\circ} \mathrm{S}$, east of the Ross Sea and south of Australia-the latter two occurring along the coast of Antarctica. In terms of transports, $2.2 \mathrm{~Sv}$ of NADW upwells in the Atlantic sector, 3.3 Sv in the Pacific sector, and $1.1 \mathrm{~Sv}$ in the Indian Ocean sector. Note that the geographical distribution of the upwelling agrees very well with the distribution of the maxima of the upward Ekman pumping (Fig. 8a). The mean meridional Ekman transport is positive for all the upwelling sites except for the southernmost coastal region in the Pacific sector (Fig. 8b), in which upwelled waters flow toward Antarctica.

In our model, the fate of the NADW upwelling is mostly into subsurface and SAMW in the Indian Ocean (2.6 Sv) and TW (SSMW) in the Pacific Ocean (2.9 Sv) (section 2; Table 2). After the first crossing of the 27.8 isosurface, most of the water parcels progress northeastward in the surface layers. The northeastward motion after the upwelling can be appreciated in the distribution of the crossing of the 27.2 isoneutral surface by the NADW water parcels (Fig. 8c) and, further, in the crossing of the 26.0 isosurface (Fig. 8d). About $60 \%$ of the NADW upwelled in the Atlantic sector is thus transported toward the Indian Ocean to finally contribute to the MW formation. Most of the NADW upwelling that occurs south of Australia and in the region adjacent to the Ross Sea is transported toward the $\mathrm{Pa}$ cific $(60 \%)$. The upwelling occurring in the Pacific sector, east of $150^{\circ} \mathrm{W}$, is entrained in the ACC, and eventually its fate is equally partitioned between the Atlantic and the Indian Oceans.

The distribution of the transport as a function of the time needed by the NADW parcels to reach the 27.8 isoneutral surface from $30^{\circ} \mathrm{S}$ is shown in Fig. 9. The
NADW upwelling presents two main time scales (peaks in the distribution). The shorter time scale, characterizing the first $60 \mathrm{yr}$ of the distribution, explains less than $10 \%$ of the total transport and is related to the upwelling along the continental slopes of the Atlantic sector. At longer times, the histogram presents a broad peak at $\sim 140 \mathrm{yr}$ and a long tail for the longest time scales. [Of interest is that the NADW timing of the upwelling found here matches previous modeling estimates on the variability of the Southern Ocean properties (Mikolajewicz and Maier-Reimer 1990; Osborn 1997).] The cumulative distribution saturates at a time scale of about 500-600 yr (not shown). The long tail is perfectly fitted by an exponential curve (not shown), and the 140-yr modal time scale is common to all the sectors of the Southern Ocean (Fig. 9). This implies a recirculation around the Antarctic continent that homogenizes the water masses before export. To determine the existence of this recirculation, we performed two specific Lagrangian simulations in which we stopped the NADW parcels first at a meridional section between South Africa and Antarctica and then in the Drake Passage. In fact, almost all of the upwelling branch of the NADW (6.7 Sv) crosses the first section $(6.5 \mathrm{~Sv})$ and the Drake Passage (5.7 Sv) before upwelling through the isoneutral surface. The upwelling branch of NADW at the section between Africa and Antarctica is still north of the ACC fronts, between $50^{\circ}$ and $40^{\circ} \mathrm{S}$ and between 1500 and $3000 \mathrm{~m}$ in the vertical direction (not shown). The typical time scale for reaching the African meridional section is only $10-20 \mathrm{yr}$, whereas $40-50$ yr are needed to reach the Drake Passage (Fig. 10a). The main upwelling time scale of 100$200 \mathrm{yr}$ is therefore the time needed to reach the subsurface layers at $60^{\circ}-70^{\circ} \mathrm{S}$ from the injection location, that is, the time scale of the ACC cross circulation (e.g., Marshall and Radko 2003). Last, the total time scale of the NADW conversion in the Southern Ocean-the time needed to reach the global section at $30^{\circ} \mathrm{S}$ from the section at $30^{\circ} \mathrm{S}$ in the South Atlantic-is only a few decades longer than the time needed for the first upwelling (Fig. 10b) and more than one-half of the water parcels reach the subtropics from the upwelling sites in less than $20 \mathrm{yr}$ (Fig. 10c).

\section{b. The role of heat and freshwater in the conversion of NADW}

The net overturning of NADW in the Southern Ocean implies net buoyancy exchanges that can be quantified as density fluxes associated with the Lagrangian pathways. The equivalent density flux is defined here as $\Phi_{d}=\sum_{n=1}^{N} \Delta \gamma_{n} \phi_{n}$, where, for each water parcel $n, \Delta \gamma_{n}$ is the difference between the final and initial 


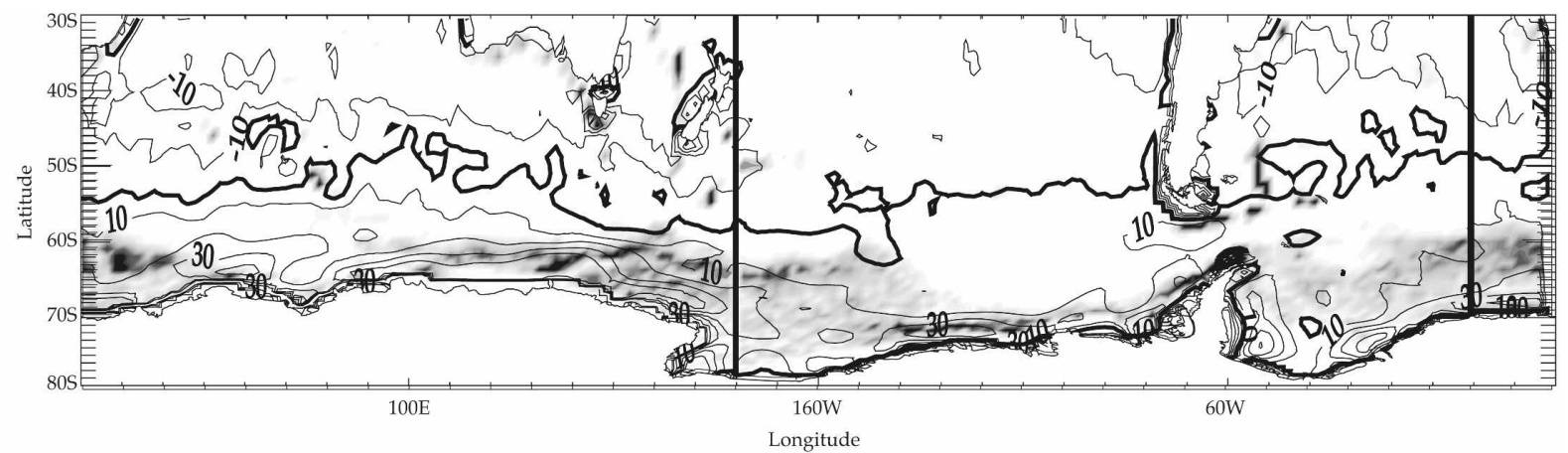

a)
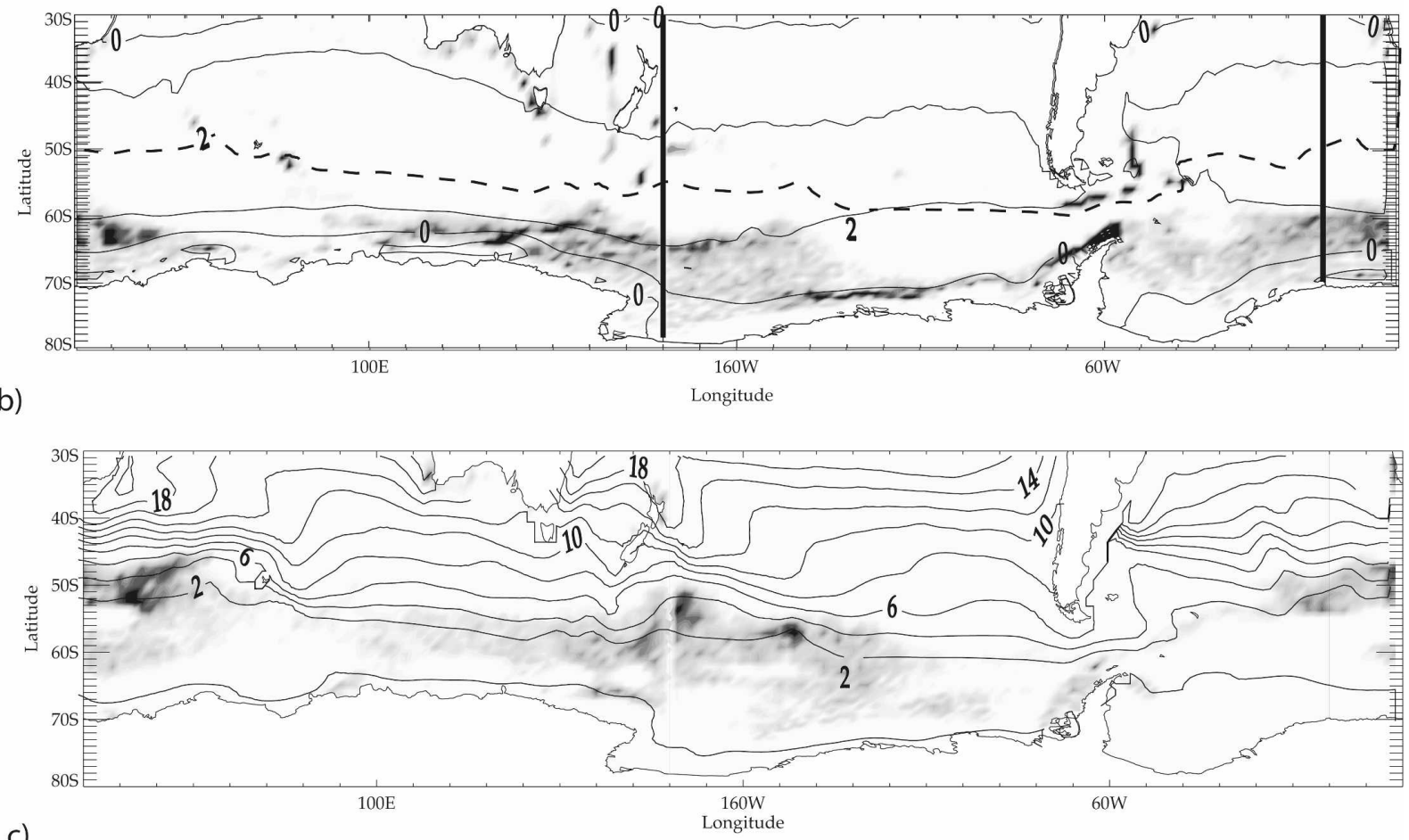

c)

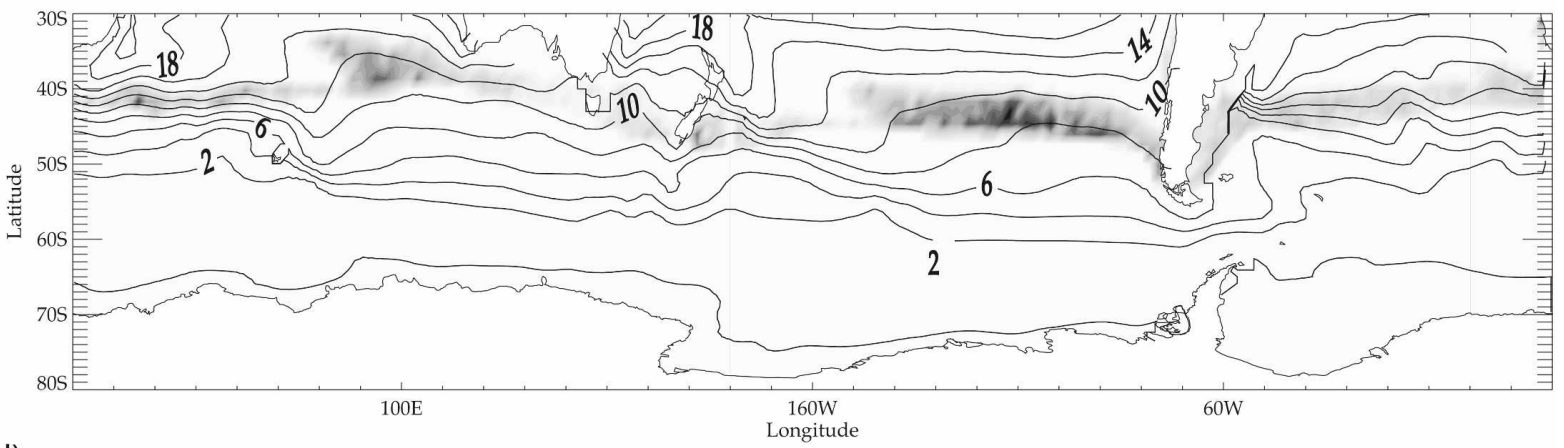

d)

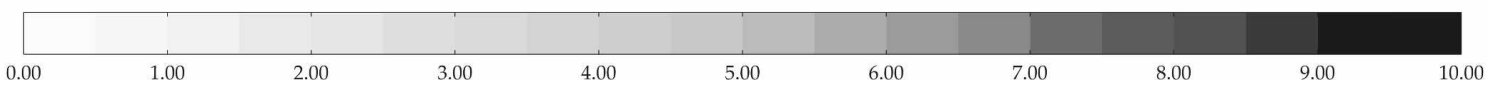

FIG. 8. (a) Geographical distribution of the NADW first crossing of the 27.8 isoneutral surface in the Southern Ocean (in equivalent dianeutral velocity; $10^{7} \mathrm{~m} \mathrm{~s}^{-1}$ ). The annual mean Ekman vertical transport is superimposed. (b) Geographical distribution of the NADW first crossing of the 27.8 isoneutral surface in the Southern Ocean (in equivalent dianeutral velocity; $10^{7} \mathrm{~m} \mathrm{~s}^{-1}$ ). The annual mean Ekman meridional transport is superimposed. The dashed line represents the mean position of the $2^{\circ} \mathrm{C}$ isotherm at $100 \mathrm{~m}$, a proxy for the position of the Polar Front. (c) Geographical distribution of the NADW first crossing of the 27.2 isoneutral surface in the Southern Ocean (in equivalent dianeutral velocity). The annual mean temperature field at $100 \mathrm{~m}$ is superimposed. (d) Geographical distribution of the NADW first crossing of the 26.0 isoneutral surface in the Southern Ocean (in equivalent dianeutral velocity). The annual mean temperature field at $100 \mathrm{~m}$ is superimposed. 


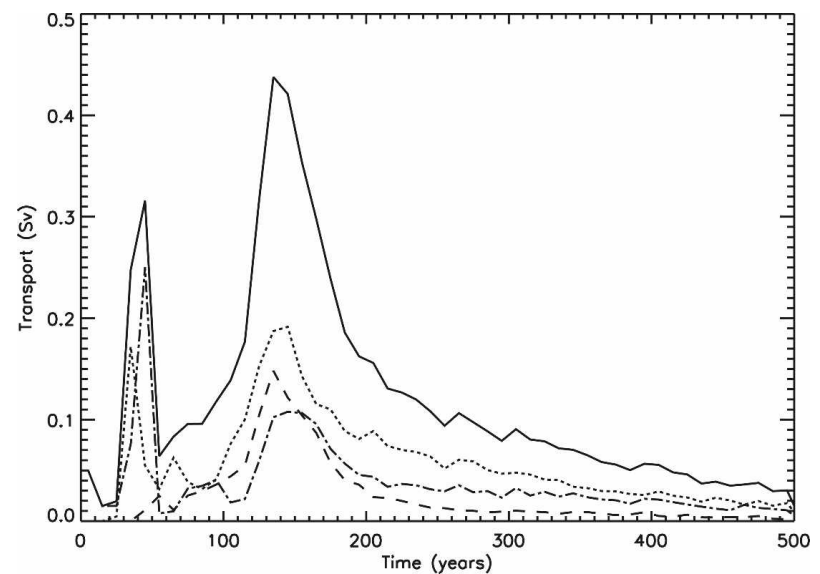

FIG. 9. Time statistics for the first crossing of the 27.8 isoneutral surface. The total transport is represented by the continuous line; the statistics for the Pacific sector are shown by the dashed line, the Indian Ocean sector statistics are shown by the dotted line, and the Atlantic sector statistics are shown by the dot-dashed line.

density values at $30^{\circ} \mathrm{S}$ and $\phi_{n}$ is the associated volume transport. The resulting values are $-11.0 \times 10^{6} \mathrm{~kg} \mathrm{~s}^{-1}$ for the upwelling, $0.56 \times 10^{6} \mathrm{~kg} \mathrm{~s}^{-1}$ for the recirculation, and $1.4 \times 10^{6} \mathrm{~kg} \mathrm{~s}^{-1}$ for the AABW production. The upwelling thus largely dominates the thermodynamic transformation of the NADW occurring in the Southern Ocean in the model.

We further decomposed the density fluxes into the heat and freshwater contributions using

$$
\Delta \gamma=b[-\alpha(\theta, S, P) \Delta \theta+\beta(\theta, S, P) \Delta S]
$$

where $\theta$ is the potential temperature, $S$ is the salinity, $P$ is the pressure, and $\alpha(\theta, S, P)$ and $\beta(\theta, S, P)$ are the expansion and contraction coefficients, respectively (McDougall 1987; Jackett and McDougall 1997). The $b$ factor is a function of space and time whose values are close to unity in most cases, especially for densities lower than 28.0. The formula above is true only locally, and therefore exact computation of the density change along a trajectory should be performed by summing the contributions per grid box. It would indeed be very complex and costly. We thus used an integral approach by taking the initial and final $\theta-S$ values and approximating (1) as

$$
\Delta \gamma \approx-\alpha(\bar{\theta}, \bar{S}, \bar{P}) \Delta \theta+\beta(\bar{\theta}, \bar{S}, \bar{P}) \Delta S,
$$

where $\bar{\theta}$ and $\bar{S}$ are the simple averages between the initial and final values, and $\bar{P}$ was selected as the depth that minimizes the error in the equality above. Factor $b$ is implicitly included in the proportionality factor. A reasonably good correspondence between the exact density change and the approximated density change is obtained by adding the heat and freshwater contributions derived above. Figure 11 shows the case of the NADW upwelling, in which a $\bar{P}$ value equivalent to a depth of $460 \mathrm{~m}$ was used. Note that $b$ was not explicitly considered and that the state equation is nonlinear; therefore this depth value is not representative of the mean depth of the transformations. The distribution of the transport as a function of the total density gain in the NADW upwelling (from $30^{\circ} \mathrm{S}$ to $30^{\circ} \mathrm{S}$; Fig. 12) presents a symmetric distribution centered at $\Delta \gamma=1.8$.
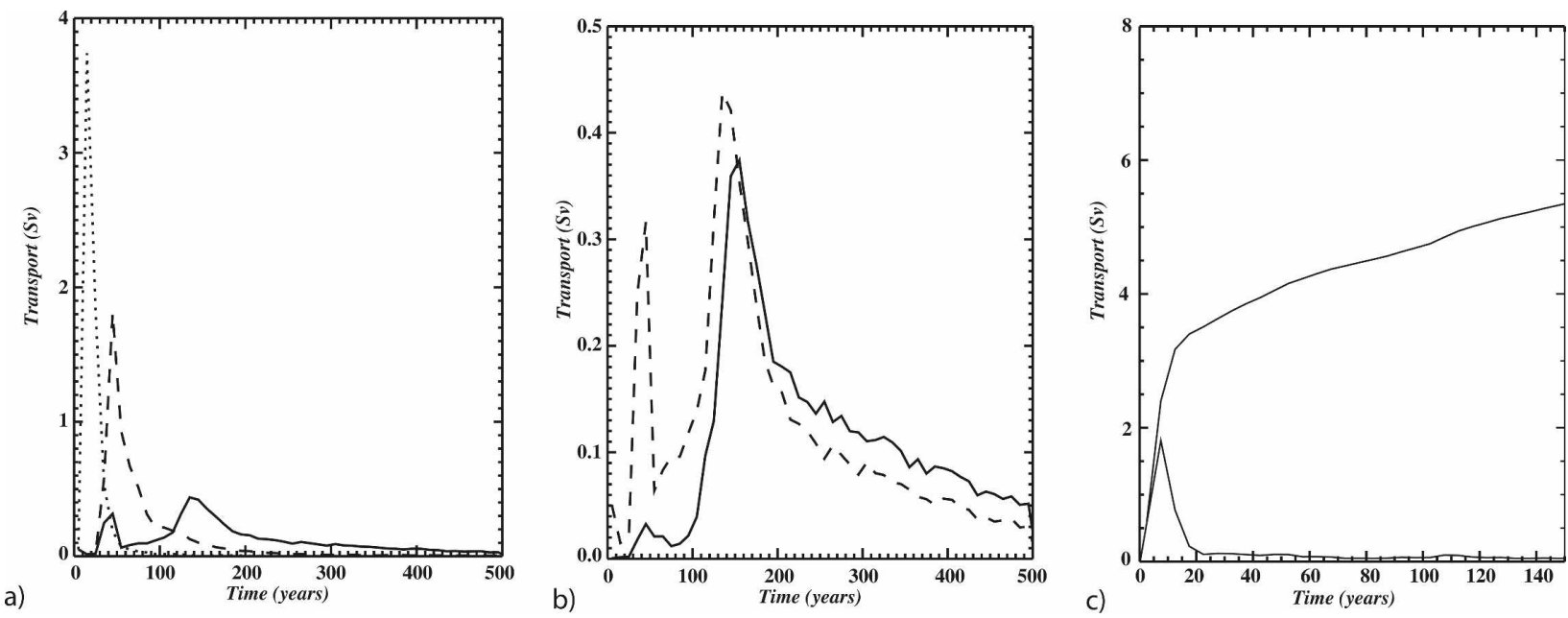

FIG. 10. (a) Distribution of the time scales associated with the transport of NADW from the South Atlantic at $30^{\circ} \mathrm{S}$ to the upwelling across the 27.8 isosurface (solid line), the Drake Passage (dashed line), and the meridional section between South Africa and Antarctica (dotted line). (b) Time scales of the connection between $30^{\circ} \mathrm{S}$ and $30^{\circ} \mathrm{S}$ for the NADW (solid line). The time scales of the upwelling across 27.8 are superimposed (dashed line). (c) Time scales associated with the pathways from the upwelling sites to $30^{\circ} \mathrm{S}$. The cumulative is also shown. 


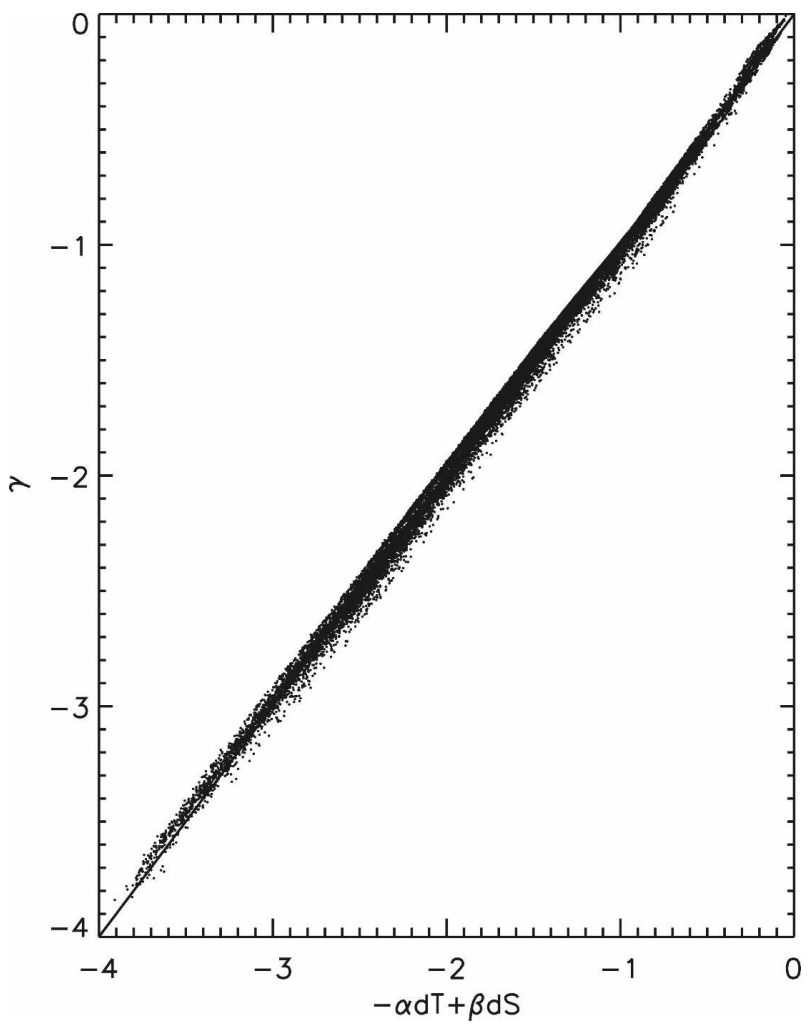

FIG. 11. Scatterplot of the density gain per water parcel expressed as the sum of the heat and freshwater contributions, approximated as in section $4 \mathrm{~b}$, vs the direct estimate. Values refer to the total density gain of the NADW upper overturning (from $30^{\circ} \mathrm{S}$ to $30^{\circ} \mathrm{S}$ )

The buoyancy gain is dominated by a net heat gain, and freshwater losses and gains basically compensate each other. The results are not surprising given the fact that TW and SAMW, the main fates for the NADW upwelling, are much warmer than NADW.

To understand better the connection between the wind-driven mechanical uplift of dense waters in the Antarctic divergence and the thermodynamics of the overturning, it is necessary to determine the nature of the buoyancy gain that allows for the first crossing in Fig. 8. The Eulerian analysis of the transformations (discussed in IMBS08 and briefly summarized in section 5) showed that CDW is transformed into IW (11 Sv) by the vertical mixing while moving upward across the large salinity gradient characterizing the base of the summer mixed layer in the polar regions. The distribution of this component of the dianeutral transport (shown in IMBS08) shows general good agreement with the distribution of the NADW upwelling (Fig. 8). The Atlantic sector presents a larger Lagrangian upwelling of NADW than the vertical diffusion would suggest. The NADW is actually only one component of

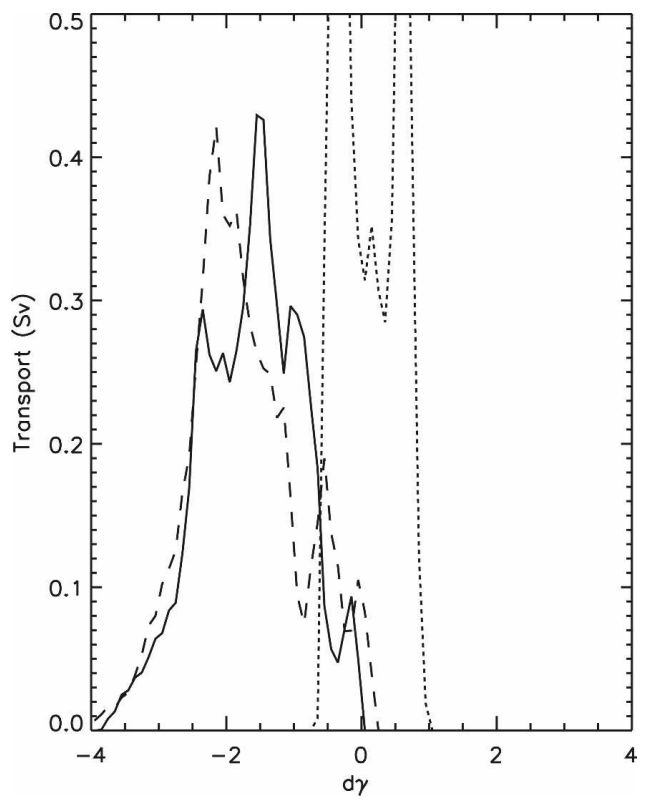

FIG. 12. Histogram of the buoyancy gain and losses associated with the upwelling of NADW in the Southern Ocean (values computed at $30^{\circ} \mathrm{S}$ ). Transport associated with each water parcel has been binned as a function of the difference between the final and initial density values. The solid line is the total transport, the dashed line is the heat component, and the dotted line is the freshwater component.

the CDW, and the whole Lagrangian CDW conversion in IW (not shown) presents a larger contribution for the Pacific than does the NADW component. Nevertheless an exact correspondence cannot be expected because our Lagrangian estimates were restricted to consider only water parcels that were in the $\mathrm{CDW}$ class at $30^{\circ} \mathrm{S}$ and not the total water transport feeding the downward diffusion of freshwater.

To further associate this purely Eulerian result with the Lagrangian NADW overturning, we used the approach above to discriminate between the roles played by heat and freshwater in the first upwelling (Fig. 13). The NADW conversion into IW is found to be entirely driven by a freshwater gain, even if a net cooling is also observed (Fig. 13). The whole CDW upwelling across the isoneutral surface presents the same phenomenology (not shown).

Last, the Eulerian vertical diffusive flux shows a marked seasonality (Fig. 14). More than one-half of the freshwater diffusive flux occurs in austral summer, when the surface layers experience the maximum stratification and relatively fresh waters at a density of about 27.4 cover the region of upwelling. On the contrary, during winter (when the outcrop occurs) the sea ice covers a large part of the region and diffusive fluxes reach their minimum values. The timing of the first 


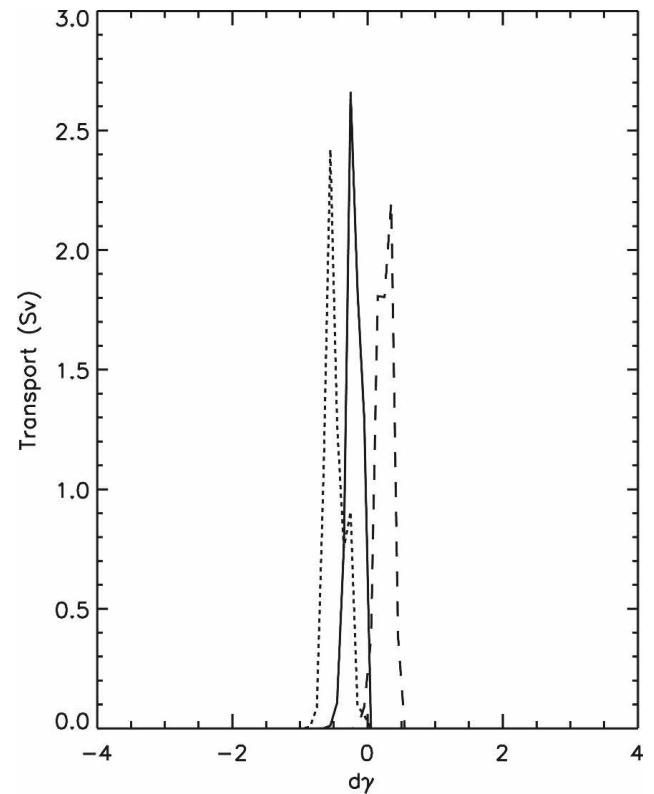

FIG. 13. As in Fig. 12, but for the NADW first crossing of the 27.8 isosurface in the Southern Ocean.

crossing of the 27.8 isosurface of the trajectories associated with the NADW in fact matches the seasonal behavior of the freshwater diffusive fluxes. The upwelling mechanism therefore does not imply an outcrop of the NADW density layer, nor is it simply related to the intensity of Ekman pumping.

\section{Water-mass pathways and the thermodynamics of the Southern Ocean thermohaline circulation}

In the previous section we described the overturning associated with the thermohaline circulation in the Southern Ocean through Lagrangian quantitative diagnostics that enabled us to track precisely the watermass paths and transformations and, in the case of the CDW upwelling, to quantify the role of heat and freshwater in the buoyancy exchanges. In a companion paper (IMBS08) quantified the dianeutral fluxes associated with each physical process involved in the transformations. Though they allow for a detailed analysis of the physics of transformations, the Eulerian analysis of dianeutral transports alone does not connect thermodynamic processes with water-mass pathways. The two results are combined here to produce a synthetic depiction of the model thermohaline circulation in the Southern Ocean, sketched in Fig. 15.

In particular, the Lagrangian analysis showed that in the ice-ocean coupled model the MW that is not recirculating $(\sim 20 \mathrm{~Sv})$ results from the combination of a shallow overturning (salty and warm TW; $70 \%$ ) with

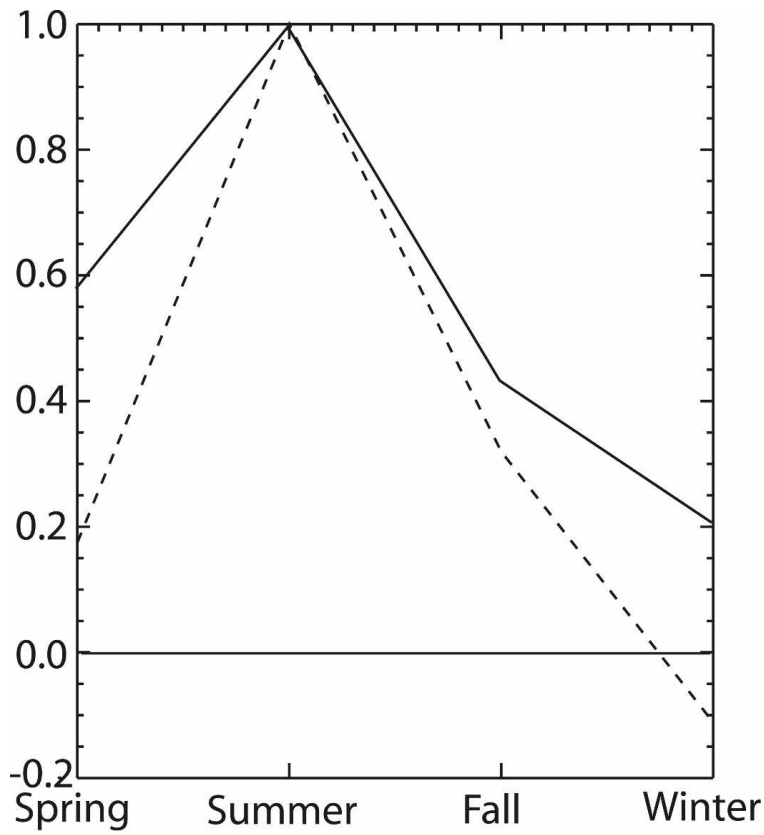

FIG. 14. Seasonal cycle of the dianeutral transport across the isoneutral 27.8 associated with the vertical diffusive processes (solid line). The seasonal cycle of the timing of the NADW first crossing of the same neutral surface is superimposed (dotted line). Values have been normalized to the summer values.

the upwelling of the CDW and IW [via the relatively fresh Antarctic Surface Water (AASW); 20\%; section 3; Fig. 15]. Model surface fluxes promote a freshwaterdriven transformation of $\sim 36 \mathrm{~Sv}$ that is partially compensated by surface cooling and finally produces a net transformation of $28 \mathrm{~Sv}$ of UCDW and IW into MW (IMBS08). The surface cooling of TW (the shallow overturning) amounts to $13 \mathrm{~Sv}$. Thus, in our simulation, there is a net formation of more than $41 \mathrm{~Sv}$ of MW. This surface formation is a partially compensated mixing process in the mixed layer, because it occurs in the North Atlantic (Marshall et al. 1999) and a net formation of $19 \mathrm{~Sv}$ of MW is observed because of the densification of $13 \mathrm{~Sv}$ of MW by vertical mixing with saltier water and the export of $10 \mathrm{~Sv}$ into $\mathrm{CDW}$ via lateral diffusion.

This result is coherent with the shallow overturning of thermocline waters into mode waters proposed by Talley (2003), with an additional significant contribution from the upwelling of dense water. These latter water masses acquire their properties in the Ekman layer, and our scenario hence explains the observation of a tight correlation between the variability of modewater tracer properties and wind intensity in subpolar regions (Rintoul and England 2002). The dominance of the conversion of salty TW in the formation of the much fresher MW implies that a large freshwater input 


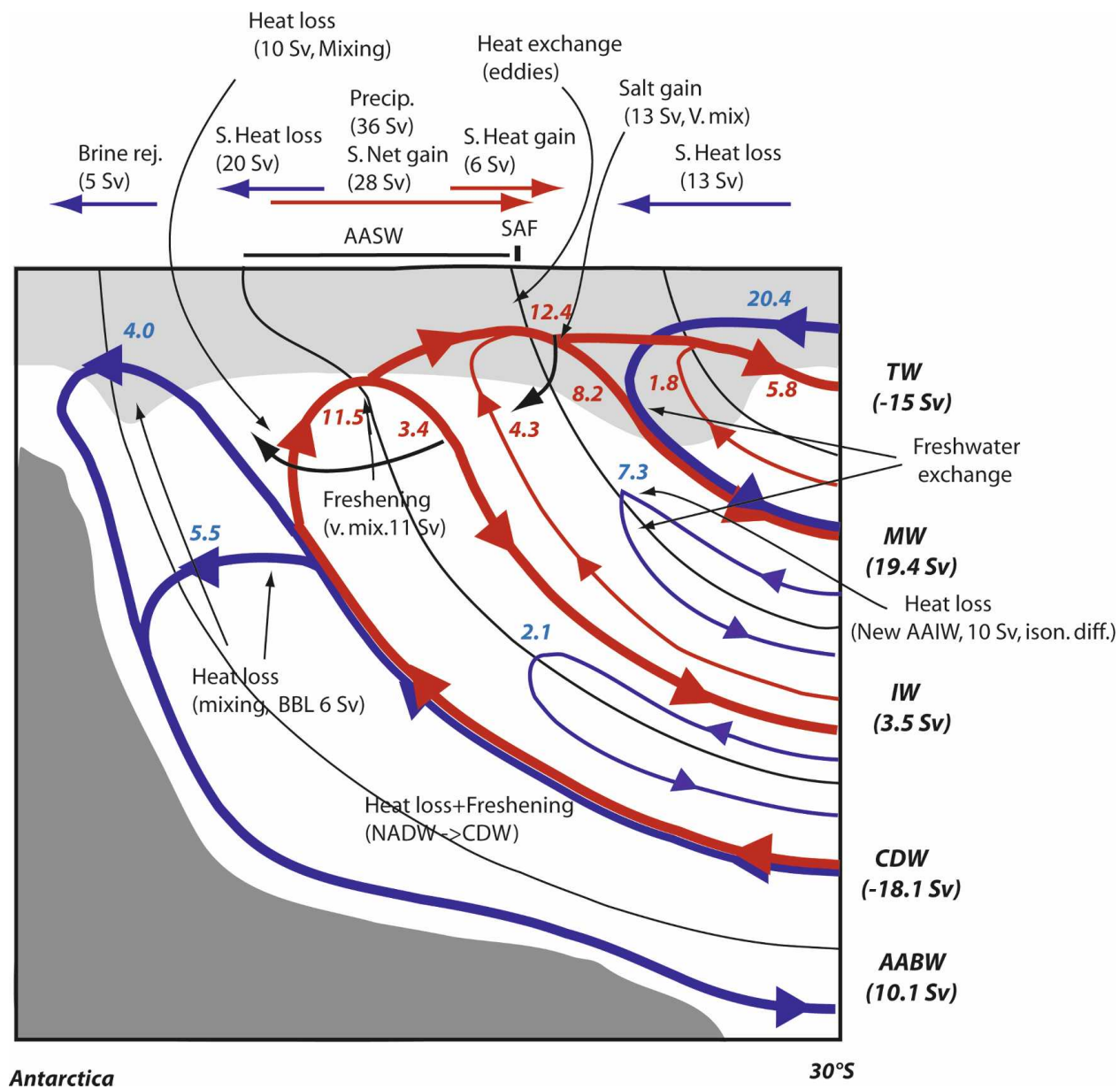

FIG. 15. A sketch of the thermohaline circulation in the Southern Ocean in the ice-ocean model (the same as in Fig. 6) with the main transformations computed by direct evaluation of the dynamical terms in the buoyancy evolution equation (see IMBS08) superimposed. Black arrows indicate the internal transformations that compensate the surface fluxes. The position of the thermodynamic processes in the sketch refers to the geographical position because some processes, such as the MW $\rightarrow$ IW transformation through vertical mixing (salt gain), are related to the seasonal cycle of the AASW south of the Subantarctic Front (see IMBS08).

is required in the MW formation; in fact, in the model, SAMW conveys the export of the polar surface freshwater excess more efficiently than does AAIW (see the discussion in IMBS08; see also Talley et al. 2004; Iudicone et al. 2005b). Regarding the AAIW, our simulation shows a relatively small production of intermediate waters even in the presence of a large buoyancy flux at the surface because vertical and lateral mixing (about $20 \mathrm{~Sv}$ ) compensate for most of the surface formation (Fig. 15). A similar result was found by Sloyan and Rintoul (2001b), who report an internal conversion of $\sim 31$ Sv. Karstensen and Quadfasel (2002) gave an estimate of $\sim 65 \mathrm{~Sv}$ for the formation of SAMW and AAIW by surface buoyancy fluxes and of $\sim 65 \mathrm{~Sv}$ for the total subduction south of $30^{\circ} \mathrm{S}$. These various formation estimates are very different in our results: $\sim 40$
$\mathrm{Sv}$ of surface production (for MW; IW is destroyed at surface); 20-30 Sv of net production in the bowl; and 75 $\mathrm{Sv}$ for the total subduction rate. The surface formation in fact corresponds to a rough estimate of the subduction (ventilation). The rectification of surface fluxes by the mixed layer has to be added to the surface formation for computing the net formation rate, and the addition generally reduces the estimates at high latitudes (see Marshall et al. 1999; Williams et al. 1995); In more general terms, the net formation in the mixed layer (by air-sea and sea-ice interactions and mixing processes) has to be compared with the subduction rates once the obduction rates are deduced (the latter process is not negligible at all in the model; see discussion in IMBS08).

Our Lagrangian estimate gives $11.5 \mathrm{~Sv}$ of net CDW 
conversion (Fig. 15) through upwelling in the Southern Ocean. The wind-driven uplift forces part of the CDW $(\sim 10 \mathrm{~Sv})$, which contains the NADW, to cross the salinity gradients below the mixed layer where vertical diffusion transforms this water into AASW in the IWdensity range (IMBS08). The net buoyancy gain at $30^{\circ} \mathrm{S}$, which is due to a heat gain, thus occurs after the upwelling into AASW. We found also that the crossing of the 27.8 isosurface occurs in most cases in concomitance with an obduction into the mixed layer (not shown). The cooler and fresher upwelled water is then exported by the Ekman northward flow (section 4). As discussed in IMBS08, a positive buoyancy budget for the mixed layer contributes to the subsequent conversion (IW into dense MW, $\gamma \approx 27.0$ ), caused by the surface freshening and a southward heat transport from lateral diffusion that partly balance the northward Ekman transport. Last, although surface thermal fluxes cool the TW in the western part of each Southern Ocean sector in the subtropics $\left(30^{\circ}-42^{\circ} \mathrm{S}\right.$; the shallow overturning), they are largely positive at the subpolar front; the dense MW component of southern origins is warmed by the atmosphere, and the differential heating there forms the MW varieties actually observed. We conclude that there is no need of positive surface heat fluxes directly acting on the dense CDW class to explain the net conversion of CDW (NADW) into TW and MW, as was proposed by several authors [see Speer et al. (2000) for a discussion].

Part of the CDW is transformed into dense AABW via surface ice brine rejection and surface cooling (Fig. $15)$. The surface formation is propagated into the interior through bottom boundary layer mixing $(6 \mathrm{~Sv})$ and lateral diffusive mechanisms; about $10 \mathrm{~Sv}$ of new AABW is produced by this CDW conversion, whose direct surface ventilation accounts for less than $35 \%$. Of interest is that the cooling associated with the first upwelling of CDW (and thus of the NADW) in our simulation is coherent with a polar upwelling of NADW (Sloyan and Rintoul 2001a,b). In particular, the small buoyancy flux into LCDW from the air-sea interactions (IMBS08) occurs in the autumn, and it is essentially a cooling that promotes the conversion into AABW; in fact NADW in the Southern Ocean is also transformed into AABW (6.5 Sv, 40\%; section 3). Therefore even if in the model AABW production is generally lower than observational estimates, the ensemble of transformations related to its formation is coherent with the deep diabatic Deacon cell proposed by Speer et al. (2000). Also, our estimate of the CDW upwelling is actually larger than previous estimates from observations of 5-8 Sv (Schmitz 1995; Ganachaud and Wunsch 2000; SR01). As discussed also by Wunsch and Ferrari (2004), data analysis shows that the LCDW density horizon outcrops under ice. The disagreement with the results from (e.g.) Sloyan and Rintoul (2001a,b) could be explained by the diffusive transport but is actually difficult to identify in data analysis and, without a proper diagnostic tool, even in model outputs.

\section{Discussion}

\section{a. The Southern Ocean and the global thermohaline circulation}

The surface fluxes in the Southern Ocean in the model solution ventilate the interior at a rate of about 40-50 Sv (net surface production), which mixed layer processes reduce to about $30 \mathrm{~Sv}$. The total (Lagrangian) ventilation of the interior amounts to $80 \mathrm{~Sv}$. The Southern Ocean also feeds the bottom layers of the Atlantic, Indian, and Pacific Ocean basins. Upwelling of bottom waters in those basins produces deep waters that contribute to maintaining the thick CDW layers while only a little amount of the bottom water reaches the subsurface waters. Thus, even if the deep vertical diffusivity is close to the higher end of the experimental estimates, the deep circulation is separated from the upper circulation and the upwelling in the Southern Ocean exceeds the tropical upwelling. In particular, only the Pacific basin allows part of the bottom water to reach the subsurface. Yet in our model, the Southern Ocean, including the subtropics to $30^{\circ} \mathrm{S}$, forms a large part of the NADW return flow into the North Atlantic via the Indian Ocean basin while the upwelling in the subtropics appears to be less important. Moreover, most of the subsurface upwelling of deep waters in the Indian and Pacific Ocean basins reenters in the shallow overturning of the Indian Ocean sector of the Southern Ocean, except for a few Sverdrups of deep upwelling into AAIW in the Indian Ocean.

Sloyan and Rintoul (2001b) recently proposed that the southern limb of the thermohaline circulation is actually the most significant component of the global thermohaline circulation (see also Schmitz 1995, 1996a,b). In the Southern Ocean large amounts of dense (bottom) water masses are formed there and, later, upwell in the Pacific and Indian Ocean basins and return to the Southern Ocean as CDW. Part of this CDW is then able to upwell into mode and intermediate waters and enter the upper thermohaline cells associated with tropical dynamics. Further, the definitive NADW upwelling occurs after a transformation into AABW, the upwelling into the UCDW horizon in the Pacific and Indian Ocean basins, and finally the exposure to positive surface fluxes in the subpolar region (Sloyan and Rintoul 2001a). The scenario proposed 
here is therefore not dissimilar to Speer et al. (2000) and SR01, augmented with the shallow overturning of Talley (2003) and Sloyan and Rintoul (2001a). Even if the simulated bottom-water formation is not as large as in SR01, the Southern Ocean basin turns out to be the most important basin for the global thermohaline circulation in terms of water-mass transformations; in fact these water masses later fill most of the World Ocean (see also Sarmiento et al. 2004).

\section{b. A dynamical connection between the Southern Ocean and NADW}

The pathways of the NADW return flow presented here are much more complex than any NADW conveyor belt picture presented before [see SR01; Sloyan and Rintoul (2001a) for a discussion]. First, the Southern Ocean splits the NADW into an upwelling branch $(40 \%)$ and a deep or bottom branch $(60 \%)$. The upwelling branch is, however, not directly toward the Atlantic and suggests one or more recirculations around Antarctica before conversion into Indian SAMW and a much more complicated pathway that includes a transformation into Indian TW and then overturning into Indian SAMW and AAIW. The rest of NADW flows into the deep and bottom layers of the Atlantic, Indian, and Pacific Ocean basins. In the Atlantic, AABW upwells into the NADW layer. The rest basically upwells in the Southern Ocean after one or more retransformations into LCDW/AABW and thus reenters into the pathways of the upwelling described above.

In our scenario the Agulhas leakage is indeed the most significant gateway because of the transitional role played by the Indian Ocean circulation. In particular, the model NADW return flow into the Atlantic basin is composed of South Atlantic SAMW and AAIW (recirculations; $~ 50 \%$ ) that freshen and cool along the Subpolar Front and of Indian SAMW, AAIW, and TW (in order of significance). Each of these water masses has a particular history of transformations (section 3 and 5), and it is difficult to draw a simple schematic of the exchanges. Nevertheless, our results do not match the schematics of the thermohaline circulation in which there is a direct connection between the NADW inflow in the Southern Ocean and the subsequent upwelling in the Indian and Pacific Oceans into TW, the so-called warm water path (e.g., Gordon 1986; Broecker 1987; Saunders and King 1995). Other authors propose instead that the NADW return flow is composed essentially of intermediate water through the Drake Passage, the "cold water path" (Rintoul 1991; Gordon et al. 1992; Schmitz 1995; Macdonald 1998; Sloyan and Rintoul 2001a). Nevertheless, Gordon et al. (1992) conclude, on the basis of the analysis of passive tracer concentrations, that intermediate water in the Benguela Current is a mixture of South Atlantic and Indian Ocean water, largely in agreement with our results. The recirculation we found does support the existence of an exchange of properties with ACC waters, but a specific study is needed to address the issue.

The scenario here proposed can be model-dependent. The very good correspondence between the model and observed chlorofluorocarbon ages on the AAIW horizon in the Atlantic (Iudicone 2007) is encouraging, but, first, the OGCM obviously does not reproduce the Agulhas Rings. Further, the interbasin exchange [and, to be specific, the SAMW/AAIW flow in the Drake Passage, underestimated in our model (IMBS08)] as well as the importance of the recirculations are sensitive to the choice of deep vertical diffusivity in the model (Iudicone et al. 2005a). Last, the actual mechanism of export of intermediate waters from the Indian Ocean to the Atlantic is unclear. The result here presented indicates the existence of a pressure gradient across the South African tip that in the model is compensated by a flow at intermediate depths; that is, the connection occurs via a relatively narrow eastern region rather than as a broad flow from the ventilation regions via the large-scale subtropical gyre. The Pacific intermediate flow from the Southern Ocean was recently found to be sensitive to the equatorial Southern Ocean meridional pressure gradient through a planetary-waves mechanism, giving rise to a longrange teleconnection (Iudicone et al. 2007). The similarity between the southeastern Pacific and the South African circulation is striking, and a similar mechanism could work. [Knutti et al. (2004) showed that in the South Atlantic the response to freshwater pulses in the NADW-formation regions is concentrated at intermediate depths.] Further observational and modeling studies are needed to understand fully the dynamics of this interbasin exchange.

The scenario proposed here does not confirm the simplified picture of a direct Southern Ocean upwelling of NADW (e.g., Döös and Coward 1997; Toggweiler and Samuels 1995; Webb and Suginohara 2001). We recall that $\sim 80 \%$ of the model net inflow of NADW into the Southern Ocean is in fact consumed in this basin but also that about $15 \%-20 \%$ of formerly NADW AABW upwells directly in the Atlantic NADW and about $40 \%$ of NADW upwells in the Southern Ocean, after one or more recirculations in the bottom cell, or in the tropics. Furthermore, in a specific sensitivity study, Iudicone et al. (2005a) contrasted the thermohaline circulation described here with the output of a simulation using a constant and weaker deep vertical diffusivity $\left(10^{-5} \mathrm{~m}^{2} \mathrm{~s}^{-1}\right)$ and found that the net 
NADW export from the Atlantic is in the latter case only slightly weaker (the difference is $\sim 10 \%$ ); that is, reducing the deep diffusivity by one order of magnitude does not affect the NADW rate of formation. They found also that in the Southern Ocean the NADW direct overturning into TW/MW/IW is $\sim 9 \mathrm{~Sv}$; that is, it is $40 \%$ larger and thus represents about $60 \%$ of the net NADW inflow. In fact, lower deep mixing implies a stronger stratification and thus shallower NADW polar depths and finally a higher efficiency in the Ekman upwelling process with respect to the export into the Indian Ocean and Pacific deep layers. Therefore, because outside the Atlantic the bottom and upper cells are connected more efficiently by the Southern Ocean (where deep anomalies emerge at the surface), a weaker bottom cell is in fact compensated by a larger Ekman export and does not affect the whole NADW production. In both cases, NADW consumption due to Southern Ocean processes is therefore approximately $80 \%-90 \%$. These results allow for some speculations. First, most of NADW is destroyed in the Southern Ocean by processes with little dependence on the NADW characteristics in the South Atlantic; thus density gradients within the Atlantic are more efficient in altering the NADW-formation rate than is the density gradient between the South Atlantic NADW and the Southern Ocean (see also Rahmstorf and England 1997). Second, in the presence of a more intense (realistic) AABW cell, the direct upwelling would presumably be lower because of the lower deep stratification. Third, the enhancement of the wind-driven upwelling could reduce the AABW-related consumption of NADW but not necessarily its consumption as a whole. The vertical displacement of NADW isoneutral surfaces around Antarctica is therefore critical in the process because it is critical for the upwelling and also for the AABW formation (e.g., Goodman 1998). Because isoneutral displacements in this region are basically wind driven (e.g., Bryden and Cunningham 2003), it is not surprising to find a sensitivity of the overturning of NADW to the subpolar winds, but the mechanism is actually much more complex than, for example, in Gnanadesikan (1999), and the various physical processes involved could compensate each other. These considerations bring up the issue of the mixing energy required to sustain the NADW thermohaline circulation (Huang 1999; Wunsch and Ferrari 2004). Webb and Suginohara (2001) gave a new (low) estimate of the deep mixing coefficient and associated extra energy input required to maintain the NADW deep upwelling, that is, the residual between the total NADW production and the Southern Ocean upwelling. Our estimate of the direct upwelling $(\sim 7 \mathrm{~Sv})$ is lower than the esti- mate of 9-12 Sv reported in Toggweiler and Samuels (1998) and in Döös and Coward (1997), but it is probably within that range when added with the indirect upwelling of the AABW return flow. In favor of their argument we found also that (i) the mixing energy required for the first step of the NADW upwelling is related to mixed layer processes and that (ii) decreasing the deep diffusivity increases the upwelling, with a mechanism different from that in Gnanadesikan (1999).

Last, to obtain an effective overturning, the mechanical view of the wind-driven NADW circulation (e.g., Toggweiler and Samuels 1995; Gnanadesikan 1999) has to be associated with a net thermodynamic transformation. In recent modeling studies Tsujino and Suginohara (1999) propose the scenario of the "windenhanced thermohaline circulation" that tentatively reconciled the mechanical and the thermodynamic perspectives (see also Klinger et al. 2004). In this scenario, part of the NADW experiences a buoyancy (heat) gain in the interior along the uplift at the wind stress divergence. The scenario we propose is similar, with the main exception being that, even if the NADW overturning in the Atlantic is heat driven, the (first) buoyancy gain in the Southern Ocean is due to the large surface freshwater excess, a result that possibly has implications on NADW dynamics on climatic scales that require further investigation with appropriate iceocean-atmosphere coupled models (e.g., air-sea freshwater fluxes are less influenced by surface water properties than by heat fluxes, and thus upwelling anomalies are dumped less efficiently).

\section{Summary and conclusions}

A detailed analysis of the global thermohaline circulation from a Southern Ocean perspective in a long simulation of an ice-ocean model was presented. The extensive use of quantitative Lagrangian diagnostics allowed identification of the main water-mass pathways and transformations. In essence, as in Schmitz (1996a,b), three main thermohaline cells characterize the model Southern Ocean: the shallow overturning of TW into MW, a deep overturning (CDW into AABW), and the net upwelling of the deep waters into TW and MW, flowing into the Pacific and Indian Oceans, respectively.

The Southern Ocean mixed layer is involved in most of the formation processes, and it ventilates the interior (the water masses flowing northward across $30^{\circ} \mathrm{S}$ ) at a rate of $80 \mathrm{~Sv}$. The Southern Ocean is a powerful consumer of CDW. The upwelling of CDW is comparable to the overturning into deep and bottom waters. The AAIW appears to be a kind of intermediate horizon, 
maintained by the cooling of old SAMW. As for the global thermohaline circulation, the Southern Ocean feeds the bottom layers in the Atlantic, Indian, and Pacific Ocean basins. Further, it feeds most of the NADW return flow, formed by Indian Ocean SAMW and AAIW. Upwelling in the deep Indian Ocean basin partially adds to the AAIW layer while the deep upwelling in the Pacific promotes an upwelling of AABW into CDW and, via the Indonesian Passage, into Indian Ocean TW. Note that the fate of Indian Ocean TW is not in the warm route of the conveyor belt (Broecker 1987), because in the Indian Ocean sector it reenters the shallow overturning. This is in agreement with the conclusions of SR01, who classified the Southern Ocean as the site of the largest water-mass transformations and systems interexchanges for the global thermohaline circulation.

About $80 \%$ of NADW exported from the South Atlantic is transformed in the Southern Ocean. The model suggests a net upwelling of NADW despite an outcropping in the cold polar regions. (The first step of the NADW upwelling is salinity driven and not heat driven.) The upwelled fraction of NADW (40\%) is obducted in the mixed layer. This occurs on time scales of 100-200 yr, essentially in the Pacific and Atlantic sectors. Because of the northeastward Ekman export, its fate is mostly Pacific TW and Indian Ocean SAMW. The main sink for NADW is Pacific AABW. There are two circuits for the NADW-circulation closure: a direct pattern, via upwelling into AASW first and then (mostly) Indian Ocean SAMW, and a much more complicated pathway made of direct and indirect upwelling into Indian Ocean TW and then overturning into Indian Ocean SAMW.

Complementing the analysis with the estimates of water-mass transformation through surface fluxes and mixing (IMBS08), we found that surface buoyancy fluxes produce $\sim 40 \mathrm{~Sv}$ of SAMW that are largely compensated by internal mixing. The upwelling of CDW through the stratified layer at the base of the mixed layer transforms $\sim 11 \mathrm{~Sv}$ into AASW/IW through the diffusive vertical propagation of the surface freshwater excess. Brine rejection, surface cooling, and significant lateral mixing with $\mathrm{CDW}$ produce the new $\mathrm{AABW}$.

The significance of these results in terms of dynamics of the global thermohaline circulation has been presented in section 6 , where we argued that the deepwater consumption in the Southern Ocean is significant and that any dynamical representation of the global thermohaline circulation has to include this net upwelling. The upwelling mechanism also has implications for the dynamics of the NADW cell. The implications for the global biogeochemical cycle (e.g., Sarmiento et al. 2004) are the subject of ongoing work.

It remains to be determined how much the weak deep overturning related to the AABW in the Indian Ocean can alter the result, possibly adding a sink for the NADW along its path to the Pacific, and we await future observational and model developments. The relatively weak SAMW transport in the model Drake Passage is also of concern for the robustness of the pathways identified here and would also merit further model development.

Acknowledgments. The authors thank Prof. Lynne Talley and the two anonymous reviewers for their most constructive and knowledgeable comments. This research was supported by the French Programe National d'Etude du Climat (PNEDC) (Project BILBO). A contribution from the Italian PNRA (Project CANOPO) is also kindly acknowledged. Computational time was provided by the Institut du Développement et des Ressources en Informatique Scientifique (IDRIS).

\section{REFERENCES}

Blanke, B., and S. Raynaud, 1997: Kinematics of the Pacific Equatorial Undercurrent: An Eulerian and Lagrangian approach from GCM results. J. Phys. Oceanogr., 27, 1038-1053.

_ S. Speich, G. Madec, and R. Maugé, 2002: A global diagnostic of interior ocean ventilation. Geophys. Res. Lett., 29, 1267, doi:10.1029/2001GL013727.

Broecker, W. S., 1987: The biggest chill. Nat. Hist., 96, 74-82.

Bryden, H. L., and S. A. Cunningham, 2003: How wind-forcing and air-sea heat exchange determine the meridional temperature gradient and stratification for the Antarctic Circumpolar Current. J. Geophys. Res., 108, 3275, doi:10.1029/ 2001JC001296.

Delecluse, P., and G. Madec, 1999: Ocean modelling and the role of the ocean in the climate system. Modeling the Earth's Climate and Its Variability, W. R. Holland, S. Joussaume, and F. David, Eds., Elsevier Science, 237-313.

de Santillana, G., and H. von Dechend, 1992: Hamlet's Mill: An Essay Investigating the Origins of Human Knowledge and Its Transmission through Myth. David R. Godine, 512 pp.

Donners, J. M. H., S. S. Drijfhout, and W. Hazeleger, 2005: Water mass transformation and subduction in the South Atlantic. $J$. Phys. Oceanogr., 38, 1841-1860.

Döös, K., and A. C. Coward, 1997: The Southern Ocean as the major upwelling zone of the North Atlantic Deep Water. International WOCE Newsletter, No. 27, WOCE International Project Office, Southampton, United Kingdom, 3-17.

England, M. H., 1993: Representing the global-scale water masses in ocean general circulation models. J. Phys. Oceanogr., 23, $1523-1552$.

Fichefet, T., and M. A. Morales Maqueda, 1997: Sensitivity of a global sea ice model to the treatment of ice thermodynamics and dynamics. J. Geophys. Res., 102, 12 609-12 646.

Ganachaud, A., and C. Wunsch, 2000: Improved estimates of global ocean circulation, heat transport and mixing from hydrographic data. Nature, 408, 453-456. 
$\longrightarrow$, and - 2003: Large-scale ocean heat and freshwater transports during the World Ocean Circulation Experiment. $J$. Climate, 16, 696-705.

Gent, P. R., and J. C. McWilliams, 1990: Isopycnal mixing in ocean circulation models. J. Phys. Oceanogr., 20, 150-155.

Gnanadesikan, A., 1999: A simple predictive model for the structure of the oceanic pycnocline. Science, 283, 2077-2079.

_ B. L. Samuels, and R. D. Slater 2003: Sensitivity of water mass transformation and heat transport to subgridscale mixing in coarse-resolution ocean models. Geophys. Res. Lett., 30, 1967, doi:10.1029/2003GL018036.

Godfrey, J. S., 1996: The effect of the Indonesian Throughflow on ocean circulation and heat exchange with the atmosphere: A review. J. Geophys. Res., 101, 12 217-12 238.

Goodman, P. J., 1998: The role of North Atlantic Deep Water formation in an OGCM's ventilation and thermohaline circulation. J. Phys. Oceanogr., 28, 1759-1785.

—_, 2001: Thermohaline adjustment and advection in an OGCM. J. Phys. Oceanogr., 31, 1477-1497.

Gordon, A. L., 1975: General ocean circulation. Numerical Models of Ocean Circulation: Proceedings of a Symposium Held at Durham, New Hampshire, October 17-20, 1972/Organized by the Ocean Science Committee of the Ocean Affairs Board, National Academy of Sciences, 39-53.

_- 1986: Interocean exchange of thermocline water. J. Geophys. Res., 91, 5037-5046.

—, R. F. Weiss, W. M. Smethie Jr., and M. J. Warner, 1992: Thermocline and intermediate water communication between the South Atlantic and Indian Oceans. J. Geophys. Res., 97, 7223-7240.

Gu, D., and S. H. G. Philander, 1997: Interdecadal climate fluctuations that depend on exchanges between the tropics and extratropics. Science, 275, 805-807.

Hasumi, H., and N. Suginohara, 1999: Atlantic deep circulation controlled by heating in the Southern Ocean. Geophys. Res. Lett., 26, 1873-1876.

Hirst, A. C., 1999: Determination of water component age in ocean models: Application to the fate of North Atlantic Deep Water. Ocean Modell., 1, 81-94.

Huang, R. X., 1999: Mixing and energetics of the oceanic thermohaline circulation. J. Phys. Oceanogr., 29, 727-746.

Iudicone, D., 2007: The role of Southern Ocean in the global thermohaline circulation inferred from an OGCM. Ph.D. thesis, Université de la Bretagne Occidentale, 206 pp.

— G. Madec, J. C. Dutay, S. Speich, and S. Calmanti, 2005a: Sensitivity of the global thermohaline circulation to deep vertical mixing. European Geosciences Union General Assembly, Vienna, Austria.

_ S. Speich, G. Madec, J. C. Dutay, and B. Blanke, 2005b: The role of the Southern Ocean in the global conveyor: Eulerian and Lagrangian analysis of an ice-ocean model. European Geosciences Union General Assembly, Vienna, Austria.

-, K. B. Rodgers, R. Schopp, and G. Madec, 2007: An exchange window for the injection of Antarctic Intermediate Water into the South Pacific. J. Phys. Oceanogr., 37, 31-49.

_ - G. Madec, and T. J. McDougall, 2008a: Water-mass transformations in a neutral density framework and the key role of light penetration. J. Phys. Oceanogr., 38, 1357-1376.

_ - G. Madec, B. Blanke, and S. Speich, 2008b: The role of Southern Ocean surface forcings and mixing in the global conveyor. J. Phys. Oceanogr., 38, 1377-1400.

Jackett, D. R., and T. J. McDougall, 1997: A neutral density variable for the world's oceans. J. Phys. Oceanogr., 27, 237-263.
Karstensen, J., 2004: Formation of the South Pacific Shallow Salinity Minimum: A Southern Ocean pathway to the tropical Pacific. J. Phys. Oceanogr., 34, 2398-2412.

— , and D. Quadfasel, 2002: Formation of Southern Hemisphere thermocline waters: Water mass conversion and subduction. J. Phys. Oceanogr., 32, 3020-3038.

Klinger, B. A., S. Drijfhout, J. Marotzke, and J. R. Scott, 2003: Sensitivity of basinwide meridional overturning to diapycnal diffusion and remote wind forcing in an idealized AtlanticSouthern Ocean geometry. J. Phys. Oceanogr., 33, 249-266.

,,--- , and,- 2004 : Remote wind-driven overturning in the absence of the Drake Passage effect. J. Phys. Oceanogr., 34, 1036-1049.

Knutti, R., J. Flückiger, T. F. Stocker, and A. Timmermann, 2004: Strong hemispheric coupling of glacial climate through freshwater discharge and ocean circulation. Nature, 430, 851-856.

Macdonald, A. M., 1998: The global ocean circulation: A hydrographic estimate and regional analysis. Prog. Oceanogr., 41, 281-382.

Madec, G., P. Delecluse, M. Imbard, and C. Lévy, 1998: OPA 8.1 ocean general circulation model reference manual. Notes Techniques du Pôle de Modélisation 11, Institut Pierre Simon Laplace, $91 \mathrm{pp}$.

Mantyla, A. W., and J. L. Reid, 1983: Abyssal characteristics of the World Ocean waters. Deep-Sea Res., 30, 805-833.

Marshall, J., and T. Radko, 2003: Residual mean solutions for the Antarctic Circumpolar Current and its associated overturning circulation. J. Phys. Oceanogr., 33, 2341-2354.

_ , D. Jamous, and J. Nilsson, 1999: Reconciling thermodynamic and dynamic methods of computation of water-mass transformation rates. Deep-Sea Res. I, 46, 545-572.

McDougall, T. J., 1987: Neutral surfaces. J. Phys. Oceanogr., 17, 1950-1964.

Mikolajewicz, U., and E. Maier-Reimer, 1990: Internal secular variability in an ocean general circulation model. Climate Dyn., 4, 145-156.

Orsi, A. H., G. C. Johnson, and J. L. Bullister, 1999: Circulation, mixing and production of Antarctic bottom water. Prog. Oceanogr., 43, 55-109.

Osborn, T. J., 1997: Thermohaline oscillations in the LSG OGCM: Propagating anomalies and sensitivity to parameterizations. J. Phys. Oceanogr., 27, 2233-2255.

Rahmstorf, S., and M. H. England, 1997: Influence of Southern Hemisphere winds on North Atlantic Deep Water flow. $J$. Phys. Oceanogr., 27, 2040-2054.

Rintoul, S. R., 1991: South Atlantic interbasin exchange. J. Geophys. Res., 96, 2675-2692.

_ and M. H. England, 2002: Ekman transport dominates airsea fluxes in driving variability of Subantarctic Mode Water. J. Phys. Oceanogr., 32, 1308-1321.

Sarmiento, J. L., N. Gruber, M. Brzezinksi, and J. Dunne, 2004: High latitude controls of thermocline nutrients and low latitude biological productivity. Nature, 426, 56-60.

Saunders, P. M., and B. R. King, 1995: Oceanic fluxes on the WOCE A11 section. J. Phys. Oceanogr., 25, 1942-1957.

Schmitz, W. J., Jr., 1995: On the interbasin-scale thermohaline circulation. Rev. Geophys., 33, 151-173.

_ 1996a: On the World Ocean circulation. Volume 1: Some global features/North Atlantic Circulation. Tech. Rep. WHOI-96-O3, Woods Hole Oceanographic Institute, 140 pp. , 1996b: On the World Ocean circulation. Volume 2: The Pacific and Indian Oceans/A global update. Tech. Rep. WHOI-96-08, Woods Hole Oceanographic Institute, 237 pp. 
Scott, J. R., and J. Marotzke, 2002: The location of diapycnal mixing and the meridional overturning circulation. J. Phys. Oceanogr., 32, 3578-3595.

Sloyan, B. M., and S. R. Rintoul, 2000: Estimates of area-averaged diapycnal fluxes from basin-scale budgets. J. Phys. Oceanogr., 30, 2320-2341.

$\longrightarrow$, and - 2001a: Circulation, renewal, and modification of Antarctic Mode and Intermediate Water. J. Phys. Oceanogr., 31, 1005-1030.

— and - 2001b: The Southern Ocean limb of the global deep overturning circulation. J. Phys. Oceanogr., 30, 143-173.

Sørensen, J. V. T., J. Ribbe, and G. Shaffer, 2001: On Antarctic Intermediate Water mass formation in ocean general circulation models. J. Phys. Oceanogr., 31, 3295-3311.

Speer, K., S. R. Rintoul, and B. Sloyan, 2000: The diabatic Deacon cell. J. Phys. Oceanogr., 30, 3212-3222.

Speich, S., B. Blanke, and G. Madec, 2001: Warm and cold water paths of a GCM thermohaline conveyor belt. Geophys. Res. Lett., 28, 311-314.

,-- , P. de Vries, S. Drijfhout, K. Döös, A. Ganachaud, and R. Marsh, 2002: Tasman leakage: A new route in the global ocean conveyor belt. Geophys. Res. Lett., 29, 1416, doi:10.1029/2001GL014586.

Stammer, D., and Coauthors, 2002: Global ocean circulation during 1992-1997, estimated from ocean observations and a general circulation model. J. Geophys. Res., 107, 3118, doi:10.1029/2001JC000888.

Stommel, H., and A. B. Arons, 1960: On the abyssal circulation of the world ocean. II: An idealized model of circulation pattern and amplitude in oceanic basins. Deep-Sea Res., 6, 217-233.

Sverdrup, H. U., M. W. Johnson, and R. H. Fleming, 1942: The Oceans: Their Physics, Chemistry, and General Biology. Prentice Hall, 1087 pp.

Talley, L. D., 2003: Shallow, intermediate, and deep overturning components of the global heat budget. J. Phys. Oceanogr., 33, $530-560$.

_ J. L. Reid, and P. E. Robbins, 2003: Data-based meridional overturning streamfunctions for the global ocean. J. Climate, 16, 3213-3226.

,-- , and -2004 : Freshwater transports of the global ocean: The role of oceans in climate. CLIVAR 2004, First Intl. CLIVAR Conf., Baltimore, MD.

Timmermann, R., H. Goosse, G. Madec, T. Fichefet, C. Ethe, and V. Duliere, 2005: On the representation of high latitude processes in the ORCA-LIM global coupled sea ice-ocean model. Ocean Modell., 8, 175-201.

Toggweiler, J. R., and B. Samuels, 1995: Effect of Drake Passage on the global thermohaline circulation. Deep-Sea Res., 42, 477-500.

_ and $\_$, 1998: On the ocean's large-scale circulation near the limit of no vertical mixing. J. Phys. Oceanogr., 28, 18321852.

TRACMASS, 2001: Tracing the water masses of the North Atlantic and the Mediterranean. Final Rep. MAS3-CT97-0142 EU MAST III project TRACMASS, $55 \mathrm{pp}$.

Tsujino, H., and N. Suginohara, 1999: Thermohaline circulation enhanced by wind forcing. J. Phys. Oceanogr., 29, 1506-1516.

Valdivieso Da Costa, M., and B. Blanke, 2004: Lagrangian methods for flow climatologies and trajectory error assessment. Ocean Modell., 6, 335-358.

Webb, D. J., and N. Suginohara, 2001: Vertical mixing in the ocean. Nature, 409, 37.

Williams, R. G., M. A. Spall, and J. C. Marshall, 1995: Does Stommel's mixed layer demon work? J. Phys. Oceanogr., 25, 30893102.

Wunsch, C., 2000: What is the thermohaline circulation? Science, 298, 1180-1181.

- and R. Ferrari, 2004: Vertical mixing, energy, and the general circulation of the oceans. Annu. Rev. Fluid Mech., 36, 281-314.

Wüst, G., 1935: Schichtung und zirkulation des Atlantischen Ozeans, das Bodenwasser und die Stratosphere (Layering and circulation of the Atlantic Ocean, the bottom water, and the stratosphere). Vol. 6, Wissenschaftliche Ergebnisse der Deutschen Atlantischen Expedition auf dem Forschungs und Vermessungsschiff Meteor, 1925-1927, Walter de Gruyter, 109-288.

You, C. Y., 1998: Dianeutral mixing and transformation of Antarctic Intermediate Water in the Indian Ocean. J. Geophys. Res., 103, 30 941-30972. 